\title{
Determination of The Efficiency of Hormones in The Propagation by Branches of National Type Cocoa
}

\author{
Cajamarca Marín Edison Stalin* \\ Ministry of Agriculture and Livestock (MAGAP) South Region, Cuba \\ *Corresponding author: Cajamarca Marín Edison Stalin, Ministry of Agriculture and Livestock (MAGAP) South Region, \\ Cuba
}

\section{ARTICLE INFO}

Received: 幽 January 28, 2021

Published: 幽 February 09, 2021

Citation: Cajamarca Marín Edison Stalin. Determination of The Efficiency of Hormones in The Propagation by Branches of National Type Cocoa. Biomed J Sci \& Tech Res 33(5)-2021. BJSTR. MS.ID.005453.

Keywords: Hormones; Rooting; Survival; Active Buds; Twigs

\section{ABSTRACT}

The cultivation of cocoa fine national type and aroma is disappearing in Ecuador, each year are more producers who prefer the clones of hybrids of high production as the CCN-51, causing an unstoppable erosion and a vulnerable genetic uniformity, exterminating completely genes are very important to maintain the diversity of the species. The conservation of the gene pool of Theobroma cacao L., provides us with an insurance against the adverse conditions that may arise in the future, ensuring food and good living. One of the main problems is the most nurseries are artisanal and are handled by staff that lacks the technical knowledge necessary to be able to propagate the planting material properly. The difficult asexual spread by grafts (limited skilled labor) and spread by twigs (seizures less than 25\%), meant to make the present work had as objective the determination of the efficiency of the hormones trade and natural origin to achieve the greatest percentage of rooting in twigs of cocoa national type, used a same substrate ratio of 1: 2: 1 (fine sand, soil, humus).

The place of propagation is built it in such a way as to allow the passage of $10 \%$ light under greenhouse with controlled conditions of temperature between $26^{\circ} \mathrm{C}$ and $32^{\circ} \mathrm{C}$ with a relative humidity of $95 \%$ within the sheaths to empty. The treatments under study were: T1, T2 Echo Cytoquin hormones, T3, T4 Hormonagro lentil extract, T5 Coconut Water tender and T6 Hormonagro polymer. The efficiency of the commercial hormones showed percentages of rooting in the twigs of cocoa national type at 45 days, 58 per cent was the highest that corresponds to T3, followed by the $14 \% \mathrm{~T} 2$ and $\mathrm{T} 110 \%$ presented the lowest percentages, the results of the T3 agree to research that showed that the use of products as rooting powders to basis of auxins have given good results in the survival of woody plants which have been propagated by different asexual methods. The efficiency of the hormones of natural synthesis showed percentages of rooting in the twigs of cocoa national type to 45 days, the T5 presented a high percentage of rooting in $52 \%$ its efficiency is corroborated, is composed by regulating hormones of growths and amino acids, allow the twigs develop the root system and new air tissues, T4 showed a percentage of rooting in $30 \%$.

The efficiency of the natural synthesis and commercial hormones presented development in outbreaks of the twigs of cocoa national rate at 45 days after the process of localizing, T1 showed greater development of outbreaks due to the functionality of the product, promotes the development of buds, T2 was the treatment with higher number of outbreaks assets by ramilla, due to the product that is a physiological activator tri hormonal, T5 showed a large number of twigs and uniformity of sprouting, in its composition the endosperm coconut fluid tender has amino acids for the synthesis of auxins in addition to contain cytokinins with which interact to the formation of new tissues. The results were obtained thanks to the methodology used and the environmental conditions in the experimental trial, in this research suggests that the most efficient treatments for the rooting of twigs of cocoa are national type T3 and T5 under the conditions used in the pilot testing. 


\section{Summary}

The cultivation of national type fine and aroma cacao is disappearing in Ecuador, every year more producers prefer clones of high production hybrids such as CCN-51, causing unstoppable erosion and vulnerable genetic uniformity, completely exterminating genes very important to maintain the diversity of the species. The conservation of the gene pool of Theobroma cacao L. provides us with insurance against adverse conditions that may arise in the future, ensuring nutrition and good living. One of the main problems is, most of the nurseries are artisanal and are managed by personnel who lack the technical knowledge necessary to be able to propagate the planting material properly. The difficult asexual propagation by grafts (scarce qualified labor) and propagation by twigs (seizures less than $25 \%$ ), implied to carry out the present work, its objective was to determine the efficiency of commercial hormones and of natural origin to achieve the highest percentage of rooting in National-type cocoa twigs.

The same substrate was used, a 1: 2: 1 ratio (fine sand, soil, humus), the propagation place was built in such a way that it allows the passage of $10 \%$ of greenhouse light with controlled temperature conditions between $26^{\circ} \mathrm{C}$ and $32^{\circ} \mathrm{C}$, with a relative humidity of $95 \%$ inside the vacuum covers. The treatments under study were: T1 Cytoquin, T2 Eco Hormones, T3 Hormonagro, T4 Lentil Extract, T5 Tender Coconut Water and T6 Hormonagro implied to carry out the present work, its objective was to determine the efficiency of commercial hormones and of natural origin to achieve the highest percentage of rooting in National-type cocoa twigs, the same substrate ratio 1: 2: 1 (sand fine, soil, humus), the place of propagation was built in such a way that it allows the passage of $10 \%$ of light under the greenhouse with controlled temperature conditions between $26^{\circ} \mathrm{C}$ and $32^{\circ} \mathrm{C}$, with a relative humidity of $95 \%$ inside of the vacuum sleeves.

The treatments under study were: T1 Cytoquin, T2 Eco Hormones, T3 Hormonagro, T4 Lentil Extract, T5 Tender Coconut Water and T6 Hormonagro implied to carry out the present work, its objective was to determine the efficiency of commercial hormones and of natural origin to achieve the highest percentage of rooting in National-type cocoa twigs, the same substrate ratio 1: $2: 1$ (sand fine, soil, humus), the place of propagation was built in such a way that it allows the passage of $10 \%$ of light under the greenhouse with controlled temperature conditions between $26^{\circ} \mathrm{C}$ and $32^{\circ} \mathrm{C}$, with a relative humidity of $95 \%$ inside of the vacuum sleeves. The treatments under study were: T1 Cytoquin, T2 Eco Hormones, T3 Hormonagro, T4 Lentil Extract, T5 Tender Coconut Water and T6 Hormonagro aimed at determining the efficiency of commercial and natural hormones to achieve the highest rooting percentage in National-type cocoa twigs, a 1: 2: 1 ratio (fine sand, soil, humus) was used.

The propagation site was built in such a way as to allow the passage of $10 \%$ of light under a greenhouse with controlled temperature conditions between $26^{\circ} \mathrm{C}$ and $32^{\circ} \mathrm{C}$, with a relative humidity of $95 \%$ inside the vacuum covers. The treatments under study were: T1 Cytoquin, T2 Eco Hormones, T3 Hormonagro, T4 Lentil Extract, T5 Tender Coconut Water and T6 Hormonagro aimed at determining the efficiency of commercial and natural hormones to achieve the highest rooting percentage in National-type cocoa twigs, a 1: 2: 1 ratio (fine sand, soil, humus) was used, The propagation site was built in such a way as to allow the passage of $10 \%$ of light under a greenhouse with controlled temperature conditions between $26^{\circ} \mathrm{C}$ and $32^{\circ} \mathrm{C}$, with a relative humidity of $95 \%$ inside the vacuum covers. The treatments under study were: T1 Cytoquin, T2 Eco Hormones, T3 Hormonagro, T4 Lentil Extract, T5 Tender Coconut Water and T6 Hormonagro the propagation site was built in such a way as to allow the passage of $10 \%$ of light under a greenhouse with controlled temperature conditions between $26^{\circ} \mathrm{C}$ and $32^{\circ} \mathrm{C}$, with a relative humidity of $95 \%$ inside the vacuum covers. The treatments under study were: T1 Cytoquin, T2 Eco Hormones, T3 Hormonagro, T4 Lentil Extract, T5 Tender Coconut Water and T6 Hormonagro.

The propagation site was built in such a way as to allow the passage of $10 \%$ of light under a greenhouse with controlled temperature conditions between $26^{\circ} \mathrm{C}$ and $32^{\circ} \mathrm{C}$, with a relative humidity of $95 \%$ inside the vacuum covers. The treatments under study were: T1 Cytoquin, T2 Eco Hormones, T3 Hormonagro, T4 Lentil Extract, T5 Tender Coconut Water and T6 Hormonagro + Polymer. The efficiency of the commercial hormones showed rooting percentages in the national type of cocoa twigs at 45 days, 58\% was the highest corresponding to $\mathrm{T} 3$, followed by T2 14\% and T1 10\% that presented the lowest percentages, $\mathrm{T} 3$ results are consistent with research that demonstrated that using 
products such as rooting powders based on auxins have given good results in the survival of woody plants which have been propagated by different asexual methods. The efficiency of the hormones of natural synthesis showed rooting percentages in the national type of cocoa twigs at 45 days, the T5 presented a high percentage of rooting of $52 \%$, its efficiency could be corroborated, it is composed of growth regulating hormones and amino acids., allow the twigs to develop the root system and new aerial tissues, T4 showed a rooting percentage of $30 \%$.

The efficiency of commercial hormones and natural synthesis showed development in the shoots of the national type cocoa twigs 45 days after the rooting process, T1 showed greater development of shoots due to the functionality of the product, it promotes the development of buds, T2 was the treatment with the highest number of active shoots per twig, due to the product that is a tri-hormonal physiological activator, T5 showed a large number of twigs and sprouting uniformity, in its composition the liquid endosperm of tender coconut has amino acids for the synthesis of auxins in addition to containing cytokinins with which they interact for the formation of new tissues. To the methodology used and the environmental conditions in the experimental trial, in this research it is suggested that the most efficient treatments for rooting National-type cocoa twigs are T3 and $\mathrm{T} 5$ under the conditions used in the experimental trial.

\section{Introduction}

In Ecuador, the regions that correspond to the Coast and Amazon, the cultivation of cocoa (Theobroma cacao L.) is one of the most important because it generates high income for the country, the farmers who are dedicated to this crop are medium and small Producers in rural areas, research is essential to solve the lack of quality plant material for planting and to guarantee sustainable production over time. Currently there are no nurseries that propagate national type cocoa twigs, most of them propagate grafts and cocoa twigs of the hybrid clone $\mathrm{CCN}-51$ of high production but of ordinary quality, flavor and aroma. One of the main problems is, most of the nurseries are artisanal and are managed by personnel who lack the technical knowledge necessary to be able to propagate the material of sows properly [1]. The cultivation of fine and aroma national type cocoa is disappearing in Ecuador, every year more producers prefer clones of high production hybrids such as CCN51 , causing unstoppable erosion and vulnerable genetic uniformity, completely exterminating genes very important to maintain the diversity of this species.

The conservation of the national cacao gene pool provides us with insurance against adverse conditions that may arise in the future, ensuring food and good living. The work aims, from an agronomical point of view, to obtain clones with high and quality production with the selection of elite trees, a technique that allows us to obtain plantations resistant to pests and diseases which cause economic losses for producers in this crop. From the point of view of phytogenetic resources, it is intended to conserve the fine and aroma national cocoa without losing it over time because it is currently being reduced and replaced by clones and varieties of high production and of ordinary quality. The research aims to establish the best and most economical technique for propagating sprigs of national type cocoa, under the agroecological conditions of the EL Oro area.

\section{Overall Objective}

a) To determine the efficiency of the hormones that were used in the different treatments for the rooting of the branches of national type cocoa.

\section{Specific Objectives}

a) To determine the efficiency of the treatments with the application of the commercial products Cytokin, Eco hormones and Hormonagro in the rooting in the branches of national type cocoa at 45 days of the rooting process.

b) To determine the efficiency of treatments with hormones of natural origin through the application of lentil extract (Lens culinaris M.) and the use of tender coconut water (Cocos nucifera L.) in the rooting of the branches of national type cacao to the 45 days of the rooting process.

c) To determine the efficiency of the treatments with hormones in the development of the active shoots of the national-type cocoa twigs 45 days after the rooting process.

\section{Literature Review}

\section{Origin and Aroma of Ecuadorian Cacao}

The cocoa called long ago as the fruit of the gods has been present in the socioeconomic world for 500 years ago, cultivated mainly by tropical countries that were in the process of development, being a highly valued product in European and world gastronomy for its flavor and aroma at that time it was called the time of "the golden seed" because all the production was of fine national type cocoa of aroma and excellent quality. Cocoa at that time was the first product that set the standard of sustenance for farmers and served as an opening and link with the European market and the 
rest of the world to which the raw material is exported so that it is industrialized and elaborated a series of derived products such as chocolates, sweets, drinks, etc [2].

\section{Description of Products and Cacao Products}

Currently worldwide the market that consumes cocoa production is the chocolate industry, followed by cocoa powder and cocoa butter. One of the products made lately with national cocoa and its production increases day by day is cocoa liquor [3].

\section{Botanical Classification of Cocoa}

The botanical classification of the species (Theobroma cacao L.) is as follows [4]. Kingdom: Plantae Subkingdom: Tracheobionta Division: Magnoliophyta Class: Magnoliopsida Family: Malvaceae Order: Malvales

Genus: Theobroma Species: Theobroma cacao L.

\section{Climate Conditions for Cacao Growing}

There are many climatic and soil conditions and demands that influence the development of cocoa cultivation. It is a plant that requires field capacity in the soil, the optimal precipitation it needs to develop, and produce is 1500 to $2000 \mathrm{~mm}$ of annual rainfall, the optimum temperatures are minimum $21^{\circ} \mathrm{C}$ and maximum $32^{\circ} \mathrm{C}$, given these conditions the plant it will grow well, with abundant flowering and fruiting. Relative humidity must be between an average of $70 \%$ and $80 \%$ higher than this humidity causes phytosanitary problems, very strong winds can break branches, therefore they must be light and do not come too close to the sea because they can be loaded with chlorides of sodium and other salts that can be harmful to the crop [4]. The Altitude where cocoa cultivation develops optimally is from 30 masl to 800 masl. The soils for their normal development must have a depth of 1.50 meters and contain main elements that must be in adequate quantities in a usable form such as calcium, nitrogen, phosphorus and potassium with good drainage and high in organic matter with a pH between 6, 5 - 6.8 and preferably not very clayey [4].

\section{Morphology of The Cacao Tree}

The cacao tree has a main root that deepens after 10 years to 1.50 meters into the ground, from this main root lateral roots develop that are present in the upper part between the first $20 \mathrm{~cm}$ of the ground. The trunk grows vertically (orthotropia) and at 18 months of growth it presents 5 axillary buds that later give rise to five branches that later shape the tree. The leaves turn dark green. Although the color may vary according to the variety, they are rigid which allows them to take a horizontal posture [4]. The flowers of the cacao tree appear in inflorescences that form small prominences called "flower cushions"; They have a cauliflower origin, that is to say that they occur in the old bark of the trunk and the main and secondary woody branches, this flowering can occur all year round in a plantation but according to the climatic conditions that favor it. The cocoa fruit also called cob has a varied shape and colors depending on the ripeness of the fruit and the type of cocoa [4].

\section{Main Disease That Affects Cacao Plants in The Nursery}

The fungus (Moniliophthora perniciosa) that causes the disease called "witch's broom", mainly affects the growing parts of the plant such as shoots, flower pads and terminal parts of plants in nurseries, it manifests itself with abnormal development in diseased parts and These die after a few weeks, after which the fruitful part of the fungus comes out, which constitutes its propagation [4]. This disease caused by this pathogen is the one that causes economic losses worldwide, infects growing shoots causing phytosanitary problems to the crop, the spores caused by this fungus have a short life and are photosensitive [5].

\section{Genetic Classification of Cocoa}

The species (Theobroma cacao L.) is classified into 3 genetic groups Creole, outsider and a third that results from the natural cross of the criollo and outsider called Trinitarian [6,7]. Creole cocoa has the characteristic of a tree of little vigor and low yield, standing out in high quality in its seeds with a characteristic fine aroma, the cotyledon has a color between brownish ivory and very light brown, the world production is between 5 and $10 \%$, on the other hand, the foreign cocoa corresponds to a tree which has greater tolerance to diseases than the Creole cocoa and its world production corresponds to $80 \%$ and finally the Trinidadian cocoa, this tree resulted from the cross between the Creole cocoa and the foreign cocoa is very resistant to diseases but of much lower quality its seed in aroma and flavor than the creole, its production is between 10 and $15 \%$ [8].

\section{Growth and Development Mechanisms in Plants}

Natural growth in plants is due to a small number of natural substances in them, which form a combination of various different biophysical and biochemical events in which various processes occur such as the initiation of roots, periods of rest, growth rate, among others and all these processes are under the control of the various natural hormones that are synthesized in the different parts of the plant [9].

\section{Control of Development and Growth in Plants}

All growth and development activities in plants are due to their genetic code where all the information is responsible for all processes to take place with total normality, where all cells undergo division in the stages of growth and development in order to that each organ of the growing plant parts develops with its own modality [9].

\section{Phytohormones}

Plants have substances that are synthesized from them that intervene in growth and development when they have normal physiological growth, these substances are known as 
phytohormones, which are known of 4 types as auxins, cytokinins, gibberellins and ethylene, produced in different organs of the plant and are mobilized to other parts or site of action in low concentrations to regulate physiological processes, these organic compounds act in small amounts that promote, inhibit or modify any physiological process in the plant so that it can carry all its normal life cycle $[9,10]$. It is the function of phytohormones to regulate the growth rate of different parts of the plant.

\section{Auxins}

This phytohormone plays an important role in the normal physiological development of plants, with the expansion of stem and coleoptile cells, it also fulfills other important functions such as the interaction with cytokinins and the efficacy to initiate the formation of roots in many Plant species since they also stimulate cell division, thus promoting the development of calluses for the growth of roots in asexual propagation [9]. It promotes the formation of lateral and adventitious roots, delaying the abscission of leaves. One of the main effects of this hormone is that it is linked to the initiation of root primordia [11]. It intervenes in the development and formation of adventitious roots that are promoted by this phytohormone such as indole-3-acetic acid (IAA) and indole-3-butyric acid (IBA) [12] The synthesis of this phytohormone is carried out by two main physiological pathways, the first is dependent on tryptophan and the second is independent of tryptophan but is derived from a precursor of it [13].

There are two physiological mechanisms for the transport of this hormone, the first is long distance transport which is important for the normal development of lateral roots, the second is short distance transport involved in multiple processes such as root morphogenesis, flowers and fruits [14,15]. Different studies have shown that part of the action of auxins regulates the expression of genes that encode the biosynthesis of gibberellins since the expression of some genes of gibberellins was found altered by dominant auxin alleles, these hormones that interact simultaneously allow them to participate in the process of root development [16].

\section{Giberelines}

This phytohormone has the function of stimulating cell division and prolongation such as the growth of stems and internodes in an accelerated way, other functions are that they increase the content of auxins in the plant that can later be transported to the place of action in the formation roots and other organs [9]. It participates in the elongation of the cells of the endodermis of the root tissue, controlling and regulating the growth of the roots in the plant [17].

\section{Cytokinins}

They intervene in cell growth and division, which interact with auxins in the induction and promotion of the formation of organs such as flowering, root production, etc [9]. The synthesis of this phytohormone in plants occurs naturally both in the roots and aerial organs and they move where it is needed in the site of action, they also interact with both the auxin hormone and with environmental factors such as light [18].

\section{Respiration, Photorespiration and Transpiration in Plants}

Respiration in plants is a process in which there is an exchange of gases with the environment, and in this process there is a release of energy due to the oxidation of organic substances inside the mitochondria in the cell, it should be emphasized that the amount of mitochondria in a cell depends on its activity or energy demand of the cell, for respiration to occur depends on enzymes that are in and around these mitochondria, therefore respiration is a chain of chemical reactions that involve cellular processes in which are involved in specific enzymes in the degradation process in the burning of sugars, which step by step releases energy in small amounts of which the resulting products are carbon dioxide $\left(\mathrm{CO}_{2}\right)$, water $\left(\mathrm{H}_{2} \mathrm{O}\right)$ and heat; Photorespiration is a process in which it is useful for plants since it serves to dissipate the excess energy that comes when the light intensity is too high [9].

Transpiration in plants is a process which implies the loss of water from them, this process causes the plant to take carbon dioxide from the atmosphere through the pores of the stomata but at the same time by diffusion the water comes out in the form of steam, this process allows the entry of $\mathrm{CO}_{2}$ but this process implies that the plant must retain as much water as it is possible to keep the cells turgid; transpiration creates a transport system that allows the plant to mobilize nutrients and transports them to the roots caused by the flow of water through the entire plant [9].

\section{Water Absorption and Ascent of Savy In Plants}

There are various processes that intervene in the absorption and movement of water through the different tissues, the loss of water through the leaves due to transpiration must be compensated by the absorption and transport of water from the soil to the roots, in this In the process, the water is diffused directly to the root tissue that has free and direct access, the forces that determine the passive movement of water, most are environmental that do not depend on the plant [9]. In a plant when part of it is pruned, the stem exudes water with a measurable pressure that can equal up to 0.2 to $0.3 \mathrm{Mpa}$ (Megapascal), this force causes the water to move to the aerial part of the plant slowly, this This mechanism allows the plant to fill the xylem vessels that are empty or that have lost water due to the effect of this defense mechanism, the pressure can be very low when the transpiration is very high in the plants and because of that the water does not could be mobilized to the aerial parts, these forces supporting the cells may appear large, When relative humidity is lower, the water potential can reach - 100 $\mathrm{MPa}$, this difference between the potential of the foliar cells and the atmosphere makes the foliar cell surfaces lose water and generates 
a greater tension inside the cells, but thus Even by the flow of water from the internal cells and from the xylem of the foliar veins, this causes the tension to be transmitted to the water of the xylem [9].

\section{Cellular Totipotency}

It is the characteristic or capacity that a non-embryonic cell has to differentiate itself from an embryonic one and develop to become a new genotypically and phenotypically the same plant from which it comes, since it makes it possible for the vegetative parts used in asexual reproduction to have the capacity to differentiate adventitious meristems and generate new organs because each cell of the plant contains the genetic information necessary to generate a new plant and develop new plant structures [18]. Cell totipotency is possible in asexual propagation because each plant cell has specific information to generate a new plant, this involves mitotic cell divisions from which a clone of the plant genotype is finally obtained.

\section{Rhizogenesis}

Rhizogenesis is a process that encompasses a set of physiological phenomena in which roots develop, whatever asexual propagation technique is used, to promote rhizogenesis growth regulators such as auxins and other hormones are used, which by organizing root initiators that later transform into root primordia and give the formation of adventitious roots which, under suitable conditions, grow for the survival of the plant. The use of auxins must be controlled at adequate concentrations for each plant species to minimize callus formation and maximize the rate of rhizogenesis [19].

\section{Coconut Water (Cocos nucifera L.) AS Rooting}

The liquid endosperm of the seeds of the coconut plant is composed of a series of solutions containing vitamins, sugars, organic acids, inorganic ions (boron, calcium, phosphorus, potassium, zinc, magnesium, manganese, copper) amino acids (glycine, glutamic acid, tryptophan) that serve for the synthesis of auxins and the formation of new tissues, enzymes (acid phosphatase) that have the function of mobilizing phosphates in nutrient-poor soils, growth regulators (auxins and cytokinins), nitrogenous sources [20-22].

\section{Cytokin}

It is a product based on cytokinins which are produced at the tip of the root of plants and are transported to other parts where the plant needs it, this is a natural plant growth regulating hormone that promotes the development of shoots, buds and root growth especially the vigor of the plant. The application of this product promotes root growth and ensures that its growth continues since the levels of cytokinins continue in the plant [23].

\section{Eco Hormone}

It is a root biostimulant product to obtain a better development of plants in their first stages of life, it is tri-hormonal based on auxins, cytokinins and gibberellins as well as being a physiological activator that has the function of developing and improving the root system [24].

\section{Hormonagro}

This product is an excellent stimulant for the formation and production of a good root system in plants, it is ideal for all types of asexual propagation that is used. The Growth regulators that make up this product are similar to those that are synthesized naturally in plants [25].

\section{Propagation of Cocoa}

The cacao tree can be propagated by means of seed that is extracted from the ear for sexual propagation, which is necessary to know the phenotype and genotype of the mother tree from which the seed is going to be selected. It can be propagated asexually with the use of vegetative parts of the tree such as stakes or twigs, grafts and air layering, this implies that the characteristics of the mother plant will be obtained by the new plant, because it will have the same genetic makeup as the mother plant [26,27]. Asexual propagation is one of the best alternatives because it allows us a genetic improvement and with it a better productivity, as well as being a valuable alternative for the multiplication of superior genotypes [28].

\section{Asexual Propagation of Cocoa by Branches}

Methodologies have been developed to propagate cocoa twigs in an efficient and economical way, propagation by this method offers us advantages in production because the clones obtained preserve the characteristics of the mother plant [29]. The asexual propagation system by twigs has a variable rooting percentage as it is dependent on environmental conditions and the diseases that can occur during rooting [30].

\section{Technical and Environmental Factors Intervening in the Rooting Process of Cocoa Branches}

There are a number of environmental and technical factors that can influence the taking or not of cocoa twigs, among which are shown below:

\section{Greenhouse Installation}

The construction of the greenhouse and the way in which it will be built is of vital importance, therefore it must be close to a source of clean water, the land must be level and without the presence of any weeds in the area or source of contamination, in the roof of the building must be made of a material that only lets $25 \%$ of the light pass through [29].

\section{Selection of Twigs}

The twigs that must be selected for a correct rooting must be chosen from young branches with healthy and vigorous leaves which must have a brown color and do not have flowers, they must be cut in the morning so as not to expose them to high temperatures 
and do not run the risk If dehydrated, for the cut it must be at the end perpendicular to $1 / 2 \mathrm{~cm}$ from the node, these branches must have 3 to 4 leaves, in which $70 \%$ of its leaf surface will be cut [29].

\section{Shade and Sunlight}

The cacao tree, because it is a species that develops naturally in tropical conditions and native to the Amazon basin, has a preference for shade, which is why it is considered umbrophilic, and different studies show that plants that come from both sexual and asexual reproduction and that They were exposed during their growth to full sunlight and showed to be smaller and a rapid decrease in production over time. Especially in the vegetative propagation by twigs to help stimulate the formation of primordia, it is advisable to establish shade conditions of 85 to $95 \%$, with this the root primordia grow to form roots, other investigations indicate that for. A good apprehension is recommended $70 \%$ shade, on the other hand another research indicates that with a shade condition of $60 \%$ and gradually reducing this percentage of shade, good results are obtained [31]. In the process of taking on the twigs, the shadow is necessary to achieve adequate photosynthesis in the twigs, since intense sunlight would cause the stomata to close, gas exchange is reduced.

The loss of turgor in the cells and therefore the death of the twigs, these excessive levels of sunlight also cause other problems at the time of take-off, such as the photo-destruction of auxins and the concentration of growth-inhibiting substances [32]. Plants that are propagated in environments with high relative humidity and low light intensity when transferred to an external environment lose water rapidly due to the low content of epicutillary wax [33].

\section{RH}

The relative humidity conditions where the twigs must develop comprises between 90 and $100 \%$ relative humidity, with this it is achieved that the twigs undergo the evapotranspiration process and it is also possible to maintain cell turgor, to achieve those conditions of relative humidity You can place a plastic covering around it, ensuring that the internal humidity where the twigs are is saturated at night like this, or you can also place the cocoa twigs outdoors but using frequent watering for 60 days [31].

\section{Temperature}

Temperature is a very important factor in the propagation of the twigs, because due to environmental factors of temperature, light, irrigation and relative humidity, they have presented low seizures with an average of $50 \%$ [29].

\section{Substratum}

For a correct rooting of the cocoa twigs, a good rooting has been achieved in a substrate that contains rice husk, coffee or sawdust [32]. Studies have shown that the use of microorganisms such as Trichoderma sp., Pseudomonas putida and Candida utilis in substrates for cocoa plants in the nursery stage have given good results in plant development and survival in the field [34].

\section{Water Deficit and Irrigation}

The cacao tree is very sensitive to the lack of water, the stomata found in the leaves close with small changes in their content, which induces a rapid photosynthetic decrease in the leaf area of the twig [31].

\section{Growth Regulators}

The Correct form and in what concentration growth regulators such as auxins, gibberellins and cytokinins should be used is of vital importance to accelerate the process of formation of a root system in cocoa twigs, the concentration of hormones can vary depending on each species and for each clone used in the propagation [31]. In difficult rooting species, the type of hormone to be used is of vital importance for the development of the roots, the hormone AIB indole-3-butyric acid being the most recommended [35]. auxins used are indole-3-acetic acids (IAA), naphthaleneacetic (ANA) since when it is propagated by twigs, a relatively short time is used since a large number of individuals are not needed because the trees have already been previously selected [36]. The most widely used auxin for rooting is indole-3-butyric (IBA), which has given good results together with slow-release phosphate in the substrate in forest species [37]. For the asexual propagation of woody species, it is necessary to consider the type of plant, the plant material to be collected, the type of growth regulators and the environmental conditions that occur during development and climate control [38].

\section{Materials and Methods}

\section{Materials}

Trial Location: The present work was carried out in a greenhouse of the experimental area of plant genetics of the Santa Inés farm of the Academic Unit of Agricultural Sciences of the Technical University of Machala, located at km 5.5 via al Cambio, belonging to the El Cambio parish, province of El Oro Ecuador.

Geographic Location: Geographically, the study site is located between the following coordinates:

Coordinates: UTM (Universal Transverse Mercator) Datum: WGS 84 (World Geodetic System 1984) Zone: 17 Coordinate, East: $620746 \mathrm{mE}$ Coordinate, North: $9636196 \mathrm{mS}$ Altitude: $6 \mathrm{msnm}$

Climate and Ecology: According to the natural life zones of Holdridge and the ecological map of Ecuador, the test site has agroclimatic conditions with 2 to 3 hours of heliophany daily, a temperature of $25^{\circ} \mathrm{C}$ and $500 \mathrm{~mm}$ of annual precipitation that corresponds to a very dry - Tropical (bms - T).

\section{Materials}

\section{A. Field materials}

1. 300 black $6 \times 8$ polyethylene sleeves 
2. Black plastic $4 \mathrm{~m} \times 4 \mathrm{~m}$

3. 30 Vacuum covers for bananas.

4. $24 \mathrm{Kg}$ of sterilized organic matter

5. Greenhouse $4 \mathrm{~m} \times 5 \mathrm{~m}$

6. $\quad$ CP3 pump

7. Substrate ratio 1: 2: 1

8. 300 cocoa twigs

9. Zaran $2 \mathrm{~m} \times 5 \mathrm{~m}$

10. FRISONEX brand temperate

11. Hygrometer and Luxmeter

B. Products Used

1. Tender Coconut Liquid Endosperm

2. Sprouted Lentil Seed Liquid Extract

3. One $250 \mathrm{ml}$ cytokin bottle

4. A bottle of hormone 100 grams

5. A 250 cc eco hormone bottle

6. bottles of $250 \mathrm{ml}$ of formalin

7. A cover of Captain 500 grams

8. Moisture-catching polymer
Factors Evaluated: To meet the proposed objectives, 1 factor was evaluated, which is the efficiency of commercial and natural synthesis products that was used for rooting the branches of national type cocoa (Clone ETT 48), 45 days after the rooting process:

1) Efficiency of treatment 1 with the commercial product cytokin in the rooting of national type cocoa twigs, expressed in numbers.

2) Efficiency of treatment 2 with the commercial eco hormone product in the rooting of national type cocoa twigs, expressed in numbers.

3) Efficiency of treatment 3 with the hormononagro commercial product in the rooting of national type cocoa twigs, expressed in numbers.

4) Efficiency of treatment 4 with the natural synthesis hormone of lentil extract in the rooting of national type cocoa twigs, expressed in numbers.

5) Efficiency of treatment 5 with the hormone of natural synthesis of tender coconut water in the rooting of branches of national type cocoa, expressed in numbers.

6) Efficiency of treatment 6 with the commercial hormonal product + the application of the polymer to the substrate that captures water to maintain the humidity in the substrate in the rooting of national type cocoa twigs, expressed in numbers (Annex Figures 1-26).

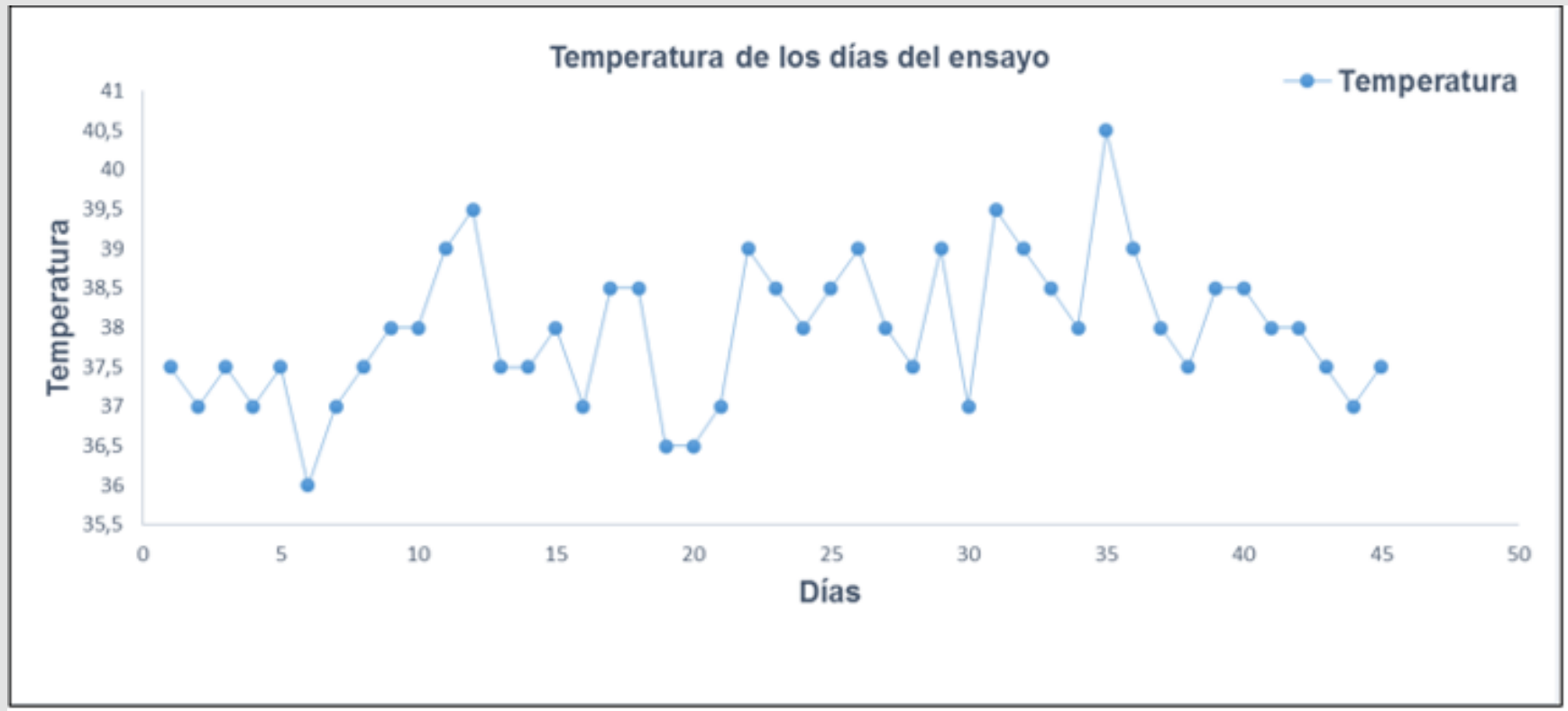

Annex Figure 1: Behavior of the environmental temperature in the greenhouse between $36^{\circ} \mathrm{C}$ and $40.5^{\circ} \mathrm{C}$ and with an average of $38^{\circ} \mathrm{C}$. Temperature obtained with a Temperate. 


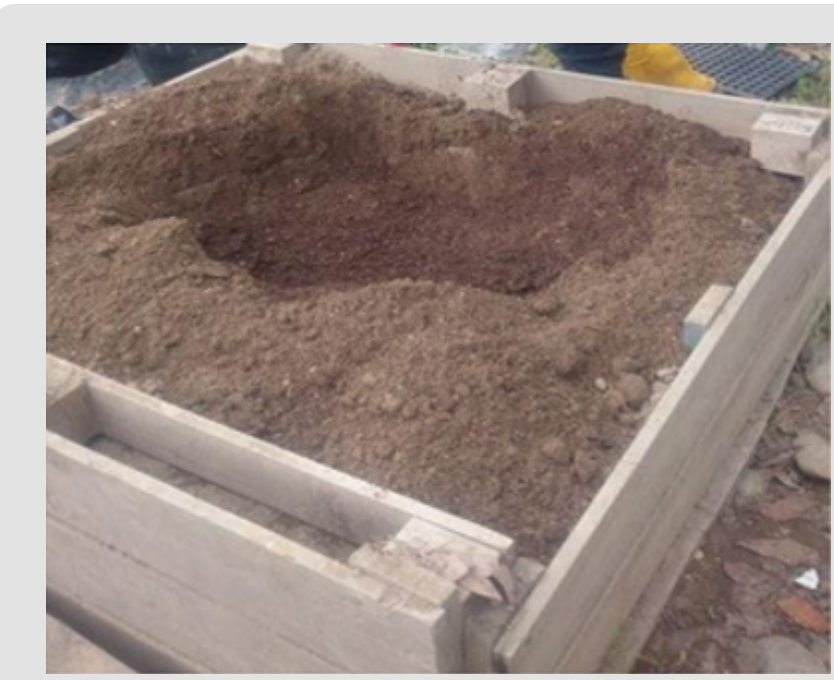

Annex Figure 2: Incorporation of humus el Substratum.

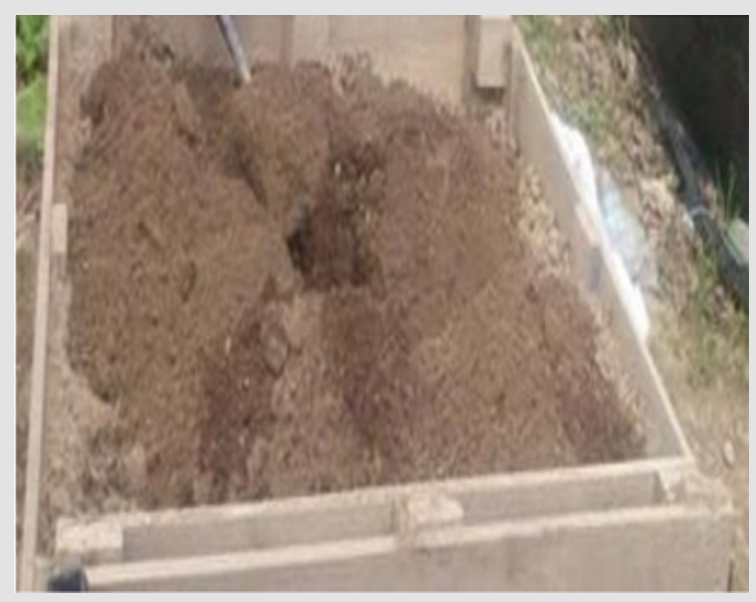

Annex Figure 3: Substrate mixing process (soil, sand and humus).

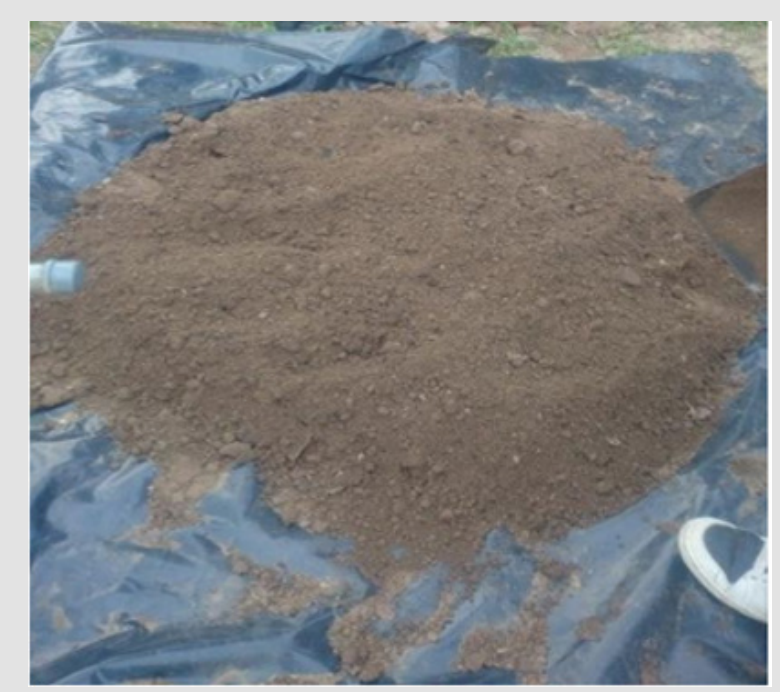

Annex Figure 4: Process of mixing the polymer to the substrate.

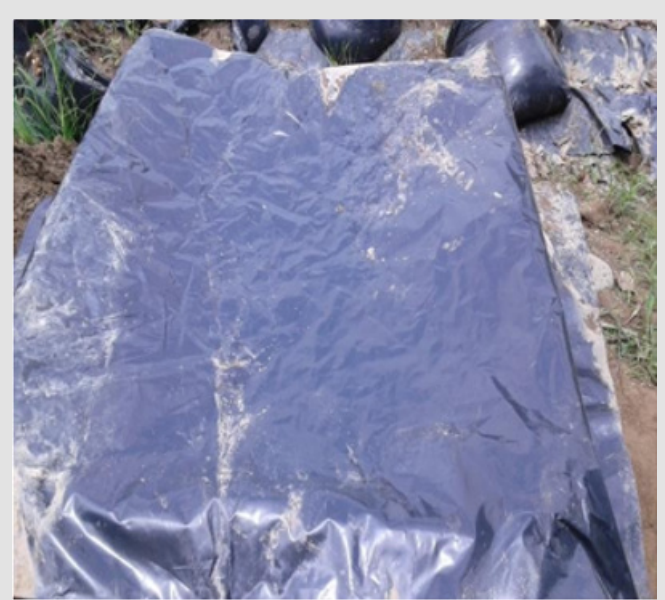

Annex Figure 5: Covering the substrate with black plastic.

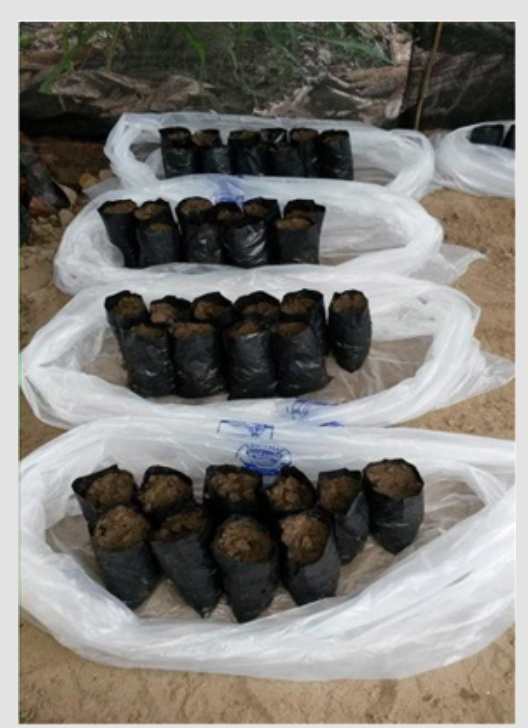

Annex Figure 6: Filling of sleeves and their placement in the vacuum sleeves.

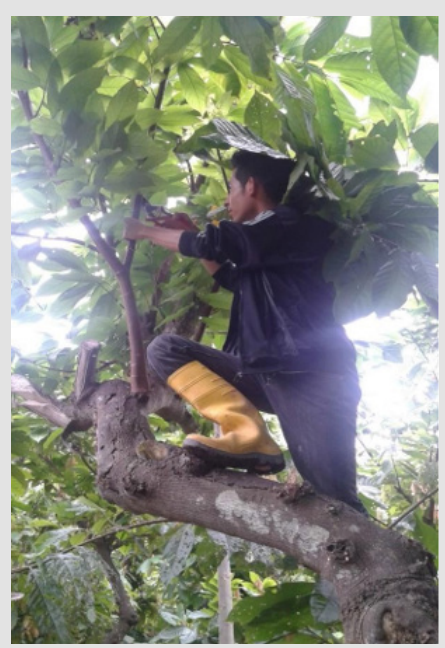

Annex Figure 7: Collection of the branches of national cocoa. 


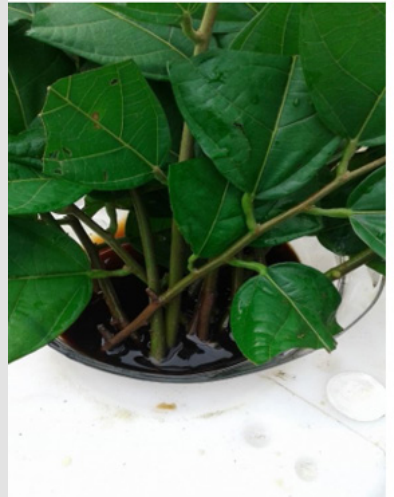

(a)

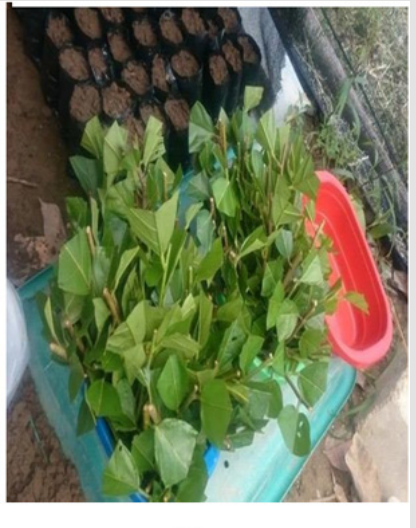

$\stackrel{(b)}{ }$

Annex Figure 8(a) and 8(b): Process of rest of the branches of national cacao in the hormones Cytoquin, Eco hormones, Lentil Extract and Tender Coconut Water.

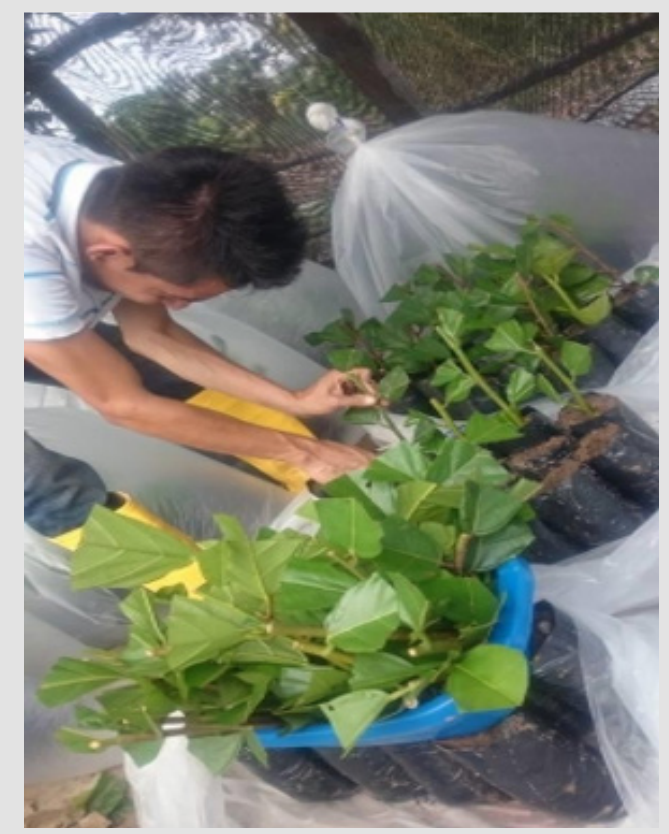

Annex Figure 9: Sowing of the branches of national cocoa.

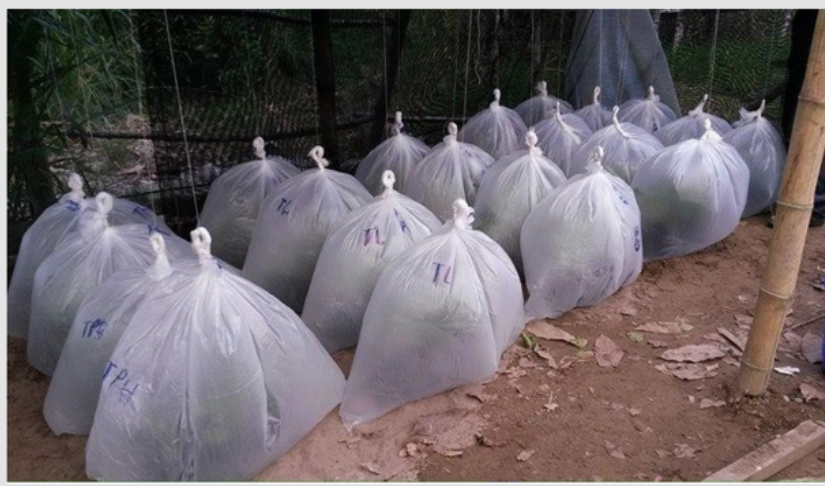

Annex Figure 10: Hormone treatments with each of your repetitions.

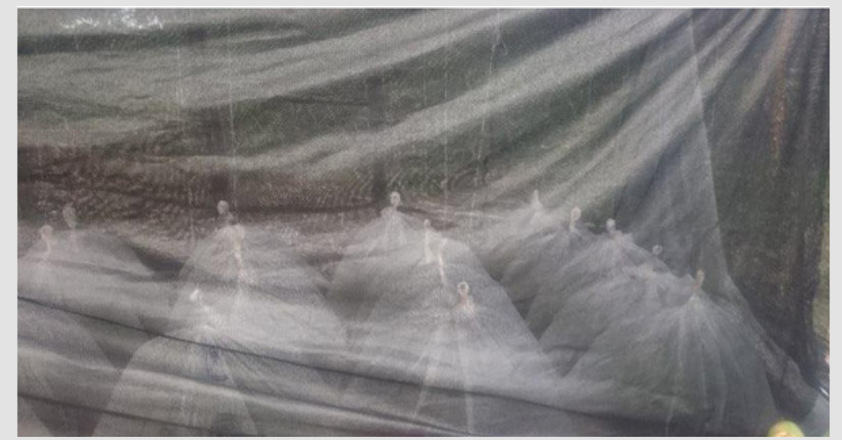

Annex Figure 11: Treatments in zaran chamber with 10\% light pass.

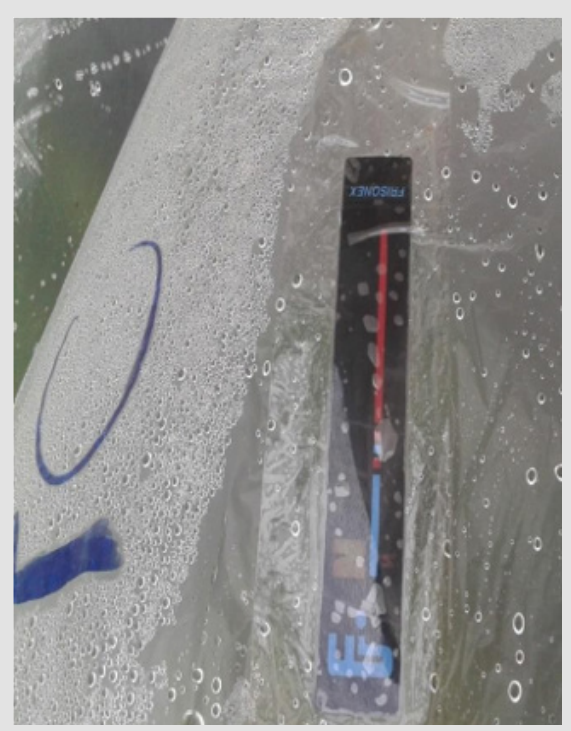

Annex Figure 12: Environmental temperature below $35^{\circ} \mathrm{C}$ within the test.

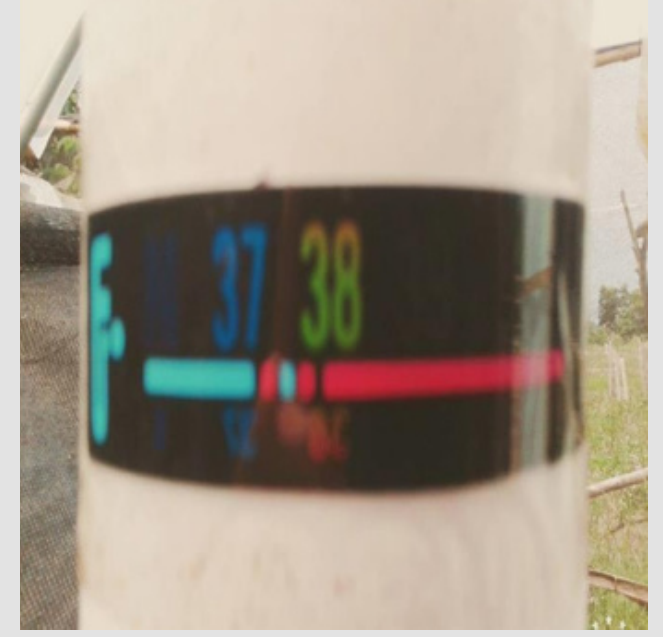

Annex Figure 13: Environmental temperature of $38{ }^{\circ} \mathrm{C}$ inside the greenhouse. 


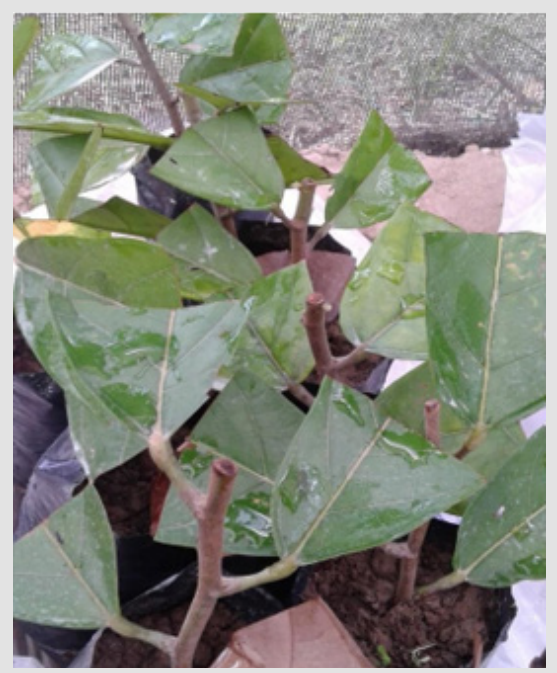

Annex Figure 14: Cacao twigs from T3 Hormonagro at 45 days.

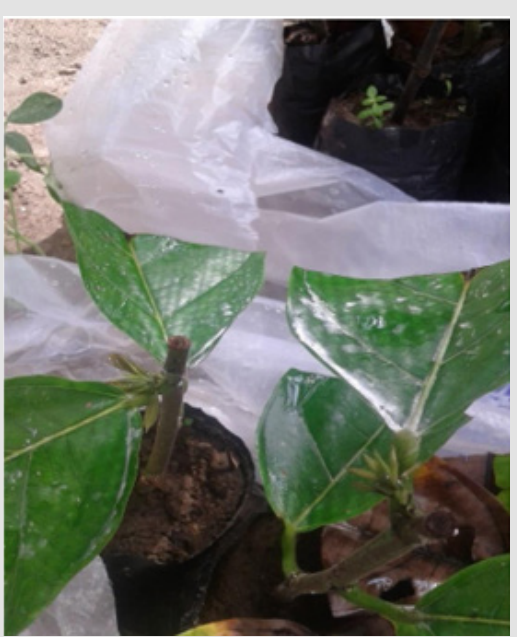

Annex Figure 15: Cacao twigs from T6 Hormonagro + Polymer at 45 days.

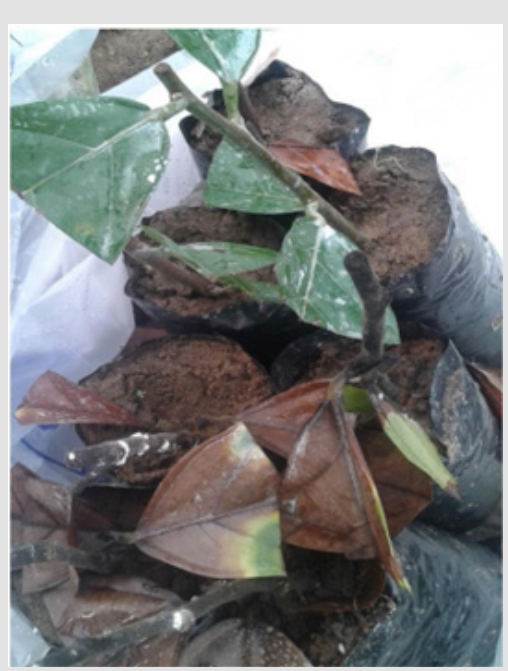

Annex Figure 16: Cocoa twigs from T4 Lentil Extract at 45 days.

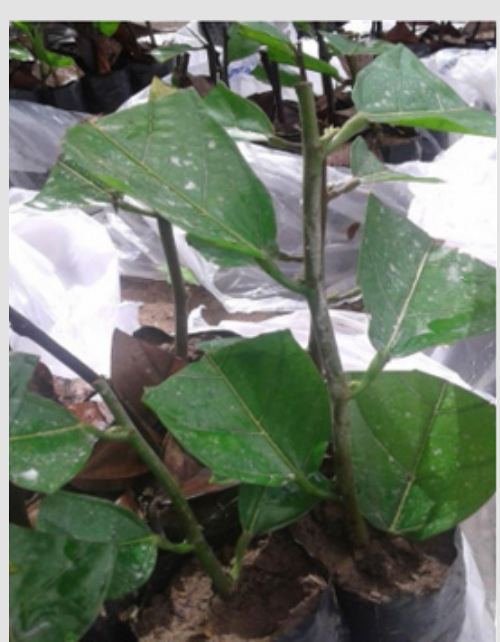

Annex Figure 17: Cacao twigs from T5 Tender Coconut Water at 45 days.

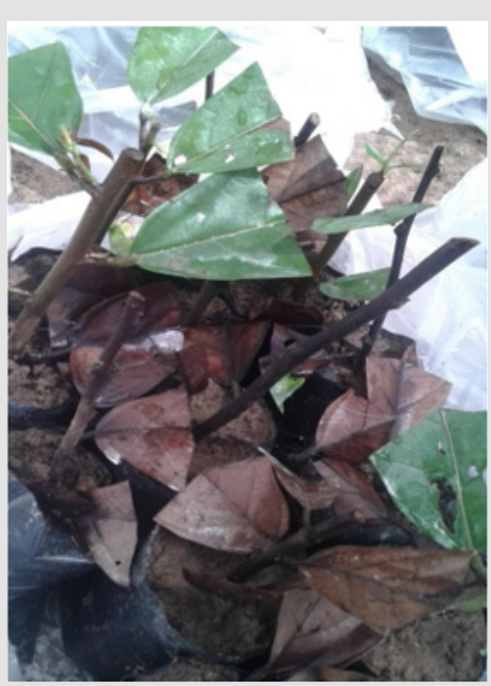

Annex Figure 18: Cocoa twigs from T2 Eco Hormones at 45 days.

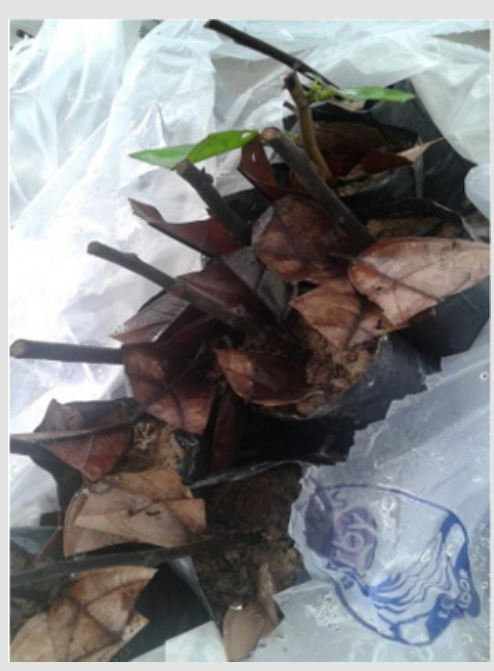

Annex Figure 19: Cacao twigs from T1 Cytoquin at 45 days. 


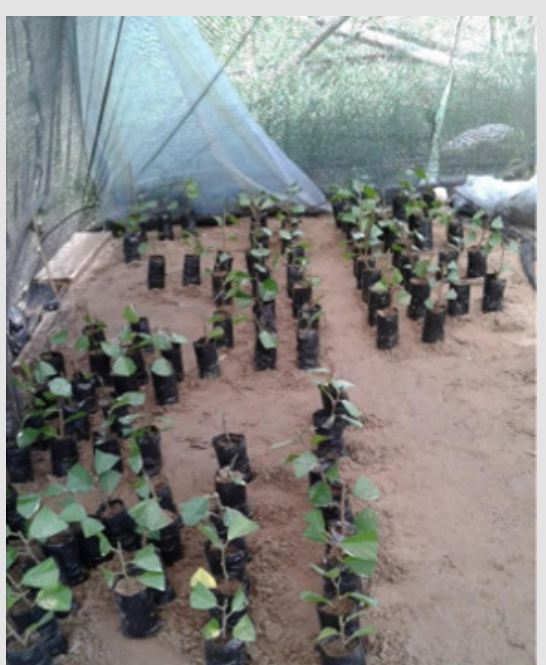

Annex Figure 20: Total rooted twigs.

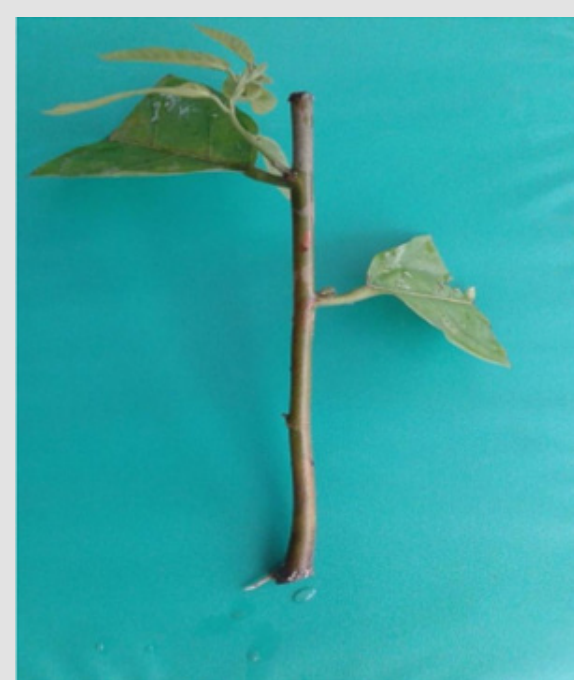

Annex Figure 21: Sprout growth and root formation at 45 days.

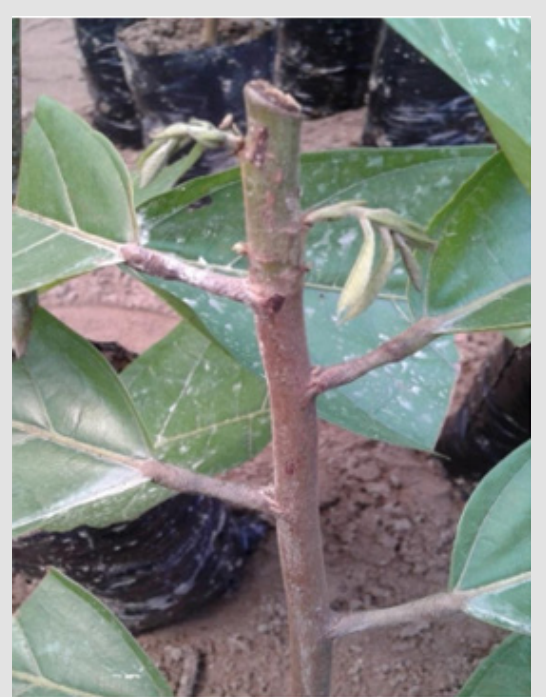

Annex Figure 22: Bouquets of national cocoa at 52 Days.

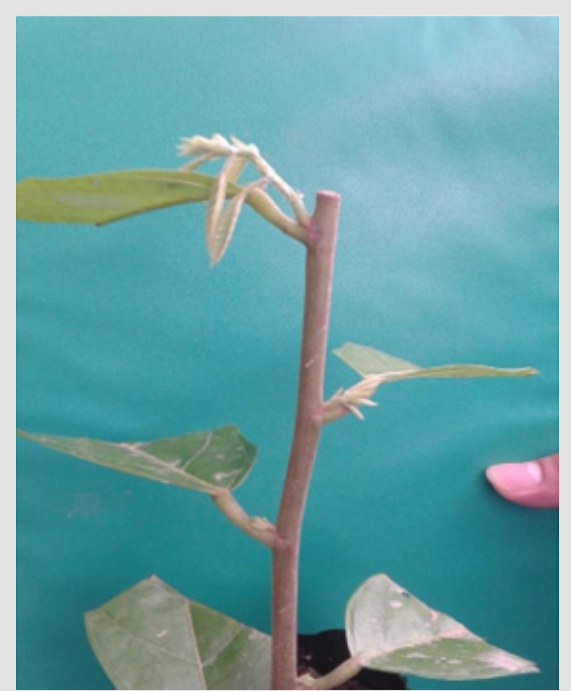

Annex Figure 23: Nationwide cocoa twigs at 59days.

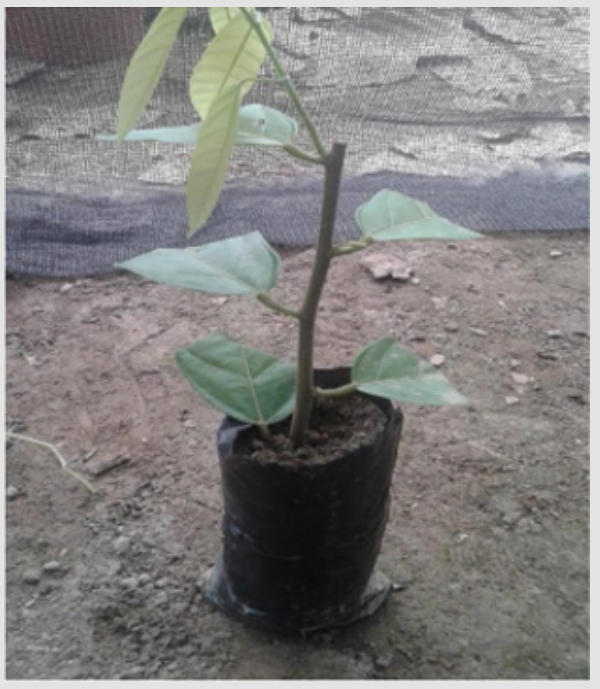

Annex Figure 24: Bouquets of national cocoa at 66 days.

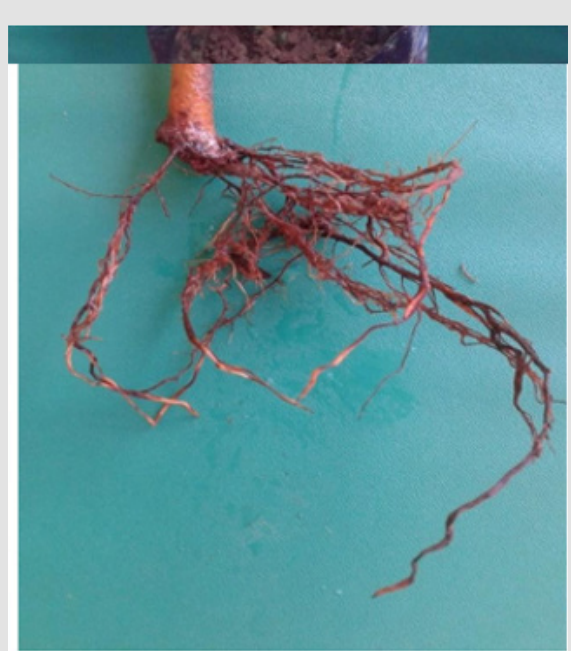

Annex Figure 25: Root system of the twigs of cocoa national at 66 days. 


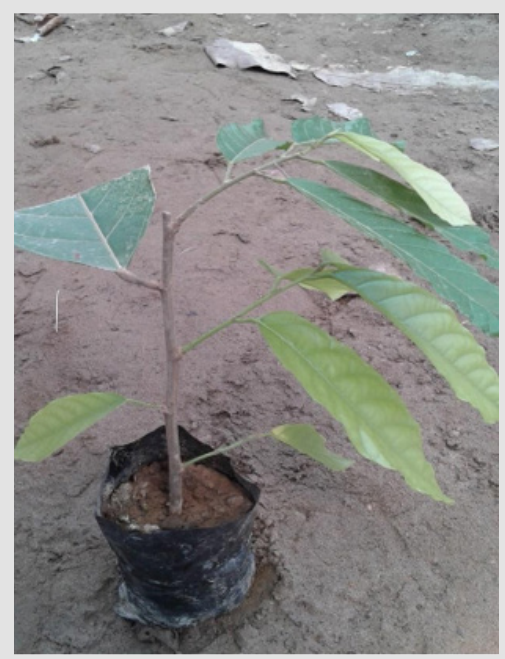

Annex Figure 26: Branch of national cocoa at 96 days to be sown in the field.

\section{Measurement of Variables}

1) Number of live twigs, number and size of active buds from treatment 1 with the commercial product cytokin. To measure this variable, the number of live twigs, the number of active buds and their measurement 45 days after starting the rooting process inside the vacuum sleeves were observed.

2) Number of live twigs, number and size of active buds from treatment 2 with the commercial product eco hormone. - To measure this variable, the number of twigs was observed

live, the number of active buds and their measurement 45 days after starting the rooting process inside the vacuum sleeves.

3) Number of live twigs, number and size of active buds from treatment 3 with the hormonal commercial product. - To measure this variable, the number of live twigs, the number of active buds and their measurement 45 days after starting the process were observed. rooting inside the vacuum sleeves.

4) Number of live twigs, number and size of active buds from treatment 4 with the natural synthesis hormone lentil extract. To measure this variable, the number of live twigs, the number of active buds and their measurement at 45 days were observed. starting the rooting process inside the vacuum sleeves.

5) Number of live twigs, number and size of active buds from treatment 5 with the natural synthesis hormone of tender coconut water. - To measure this variable, the number of live twigs, the number of active buds and their measurement at the 45 days after starting the rooting process inside the vacuum sleeves.

6) Number of live twigs, number and size of active buds from treatment 6 with the hormonal commercial product + the application of a polymer to the substrate that captures water to maintain moisture in the substrate. - To measure this variable, the number of live twigs, the number of active buds and their measurement 45 days after starting the rooting process inside the vacuum sleeves were observed.

Treatments: Six treatments based on growth hormones, commercial and naturally synthesized, were used for rooting the branches of national cocoa of the ETT-48 clone, as indicated in (Table 1). Treatments and repetitions with the different growth hormones that were applied to the national type of cocoa twigs of the ETT-48 clone, the same ones that were developed under a greenhouse inside a chamber with zaran and inside vacuum covers at the Farm Holy Ines.

\section{Methodology}

Selection of Elite Plants: Through the method used, the best plants were selected within the crop under desirable parameters and characteristics such as high production, resistance to pests and diseases. After the selection, treatments were carried out on the selected elite plants to obtain twigs of better vigor and quality:

1) The Maintenance and phytosanitary pruning to achieve the formation of new shoots and ensure young and healthy branches.

2) Elimination of flowers to ensure that the tree uses all its reserves in a balanced way in the development of branches.

3) Irrigation to the plantation is very important, to achieve physiological activation of the trees and produce more shoots.

4) The Fertilization is important to obtain vigorous branches with a well-developed and nourished foliar system without the presence of deficiencies. This process should be done 2 months before the collection of the twigs.

Substrate Preparation and Sleeve Filling: The preparation of the substrate ratio 1: 2: 1 (sand, soil and humus), we proceeded to mix $24 \mathrm{~kg}$ of sterilized organic matter with $24 \mathrm{~kg}$ of sand along with $24 \mathrm{~kg}$ of soil to obtain a better substrate for the roots of the twig's cocoa. Before placing the substrate in the sleeves, a disinfection process was carried out with formaldehyde, for this the substrate was disinfected in layers, $1000 \mathrm{ml}$ of formaldehyde were used in 20 liters of water, then the substrate was covered with a totally black plastic. After 48 hours, the black plastic was removed and the substrate was removed so that the formaldehyde and excess moisture could escape, after that process the black plastic was left on the substrate for 24 hours. A part of the substrate is separated and exposed to the sun until it loses all the humidity to later be able to include the polymer in a ratio of 5 grams of polymer in 10 $\mathrm{kg}$ of substrate if it is not dry enough the polymer will not be able to mix well with the substrate. The 250 sleeves were filled with the normal substrate and 50 sleeves with the substrate containing the moisture-conserving polymer.

Obtaining the Extract of Lentil and Coconut Water: To obtain the lentil extract, 2 pounds of lentil was soaked in water in a container until they germinated, after that time the lentils were 
liquefied together with the water, sifted and obtained the extract. To obtain coconut water, 3 freshly extracted coconuts were taken from the plant, the water was used as a rooting agent for the twigs.

Collection, Cutting, Application of Hormones and Planting of Cocoa Twigs National Type Clone ett-48: For the collection of the twigs, we proceeded to choose the trees with the best desirable characteristics in terms of resistance to pests, diseases and better production than was already chosen, this collection must be in the non-flowering and fruiting season. The twigs of young branches were cut where the upper part has a greenish-brown color and the lower part has a green color, where the axillary buds are dormant and do not present any damage by insects or any pathogenic agent. These twigs have to be about 25 to $30 \mathrm{~cm}$ long, a maximum of 4 leaves per twig were left and then their foliar area was cut by $70 \%$ to avoid loss of water due to perspiration. They were placed in a container with purified water to avoid dehydration, these twigs should be cut in the morning between 07:00 and 09:00 am to avoid the strong sun that could dehydrate them later in the day. For sowing, the base of the twigs was first cut in a bevel shape, then the twigs were placed at rest inside the containers with the pure solutions of the different commercial hormones' cytokine.

Hormonal and eco-hormone for 30 minutes and they sowed. In the solutions of hormones of natural synthesis, lentil extract and tender coconut water, it was left to rest for 45 minutes and sowed. In the hormone treatments for $\mathrm{T} 1$ and $\mathrm{T} 6$, the base of the twig was sprinkled and planted. Once all the twigs had been sown in each of their treatments, the twigs were fumigated with a fungicide. Captan was used for this research. Then the covers were sealed, it was taken into account that the vacuum covers before sealing them have to be inflated with enough air so that a microenvironment is created before closing them, with a rubber band and adhesive tape to prevent air from entering and escaping. It was tied with a rope to saran so that the covers are stable during the 45 days established until the twigs develop roots and new shoots. All treatments were under a greenhouse, in shade with two layers of saran to avoid excessive sun rays, only allowing $10 \%$ of light to pass through and to regulate the environmental temperature.

After the whole process, the Temperate was placed inside and outside the test, which allowed us to measure the environmental temperature to which the experimental test was subjected, the measurement was made every day at noon. The lux meter was used to measure how much light passed through and with the hygrometer the relative humidity was measured inside the vacuum covers. For a correct selection, cutting the twigs and achieving success in this propagation, the following steps should be followed:
a. Selection of more productive trees with fewer diseases
b. Selection of young twigs
c. Twig cutting

d. Placing the twigs in a container with purified water so that the base of the twig is submerged.

e. Twig transport

f. Cut $70 \%$ of the leaf surface.

g. Hormone application

h. Sowing in the covers, these covers must be previously already inside the vacuum covers to shorten the time of the twigs exposed to the environment.

i. Fungicide application

j. Sealing the sleeves

k. Open the covers after 45 days.

l. Air conditioning of plants for 60 days

m. Sowing in the field

Experimental Design: The experimental design that was used is a completely randomized design with the same number of observations per treatments, it was worked under a greenhouse in a homogeneous experimental environment.

\section{A. Mathematical Model}

The mathematical model was represented by the following linear equation with the variance components:

$$
Y_{i j}=U+T_{i}+
$$

$E_{i j} Y_{i j}=$ Represents the experimental unit

You $=$ Treatment effect $(i=1,2.3, \ldots \ldots .20)$

$E_{i j}=$ Experimental error $\left(E_{i j}=1,2.3 \ldots \ldots 30\right)$

$\mathrm{U}=$ Mean $=$ Overall average of the trial

\section{B. Hypothesis}

Null Hypothesis (Ho): That in all the treatments with hormones that the effectiveness in the taking and development of the twigs was used, it is not given in any treatment, therefore there is no difference between them, and the equation is fulfilled:

$$
\text { Ho }=\mu 1=\mu 2=\mu 3=\ldots \ldots . . . \mu 20
$$

Alternative Hypothesis (Ha): That in all the treatments with hormones that the effectiveness in the taking and development of the twigs was used, it was found in at least one treatment, and at least there was a difference between two means and the equation is fulfilled:

$$
\text { Нa } \neq \mu 1 \neq \ldots \ldots . . . \mu 20 \text {. }
$$

The Ho is rejected or accepted based on the following equalities:

a. If P-Value (probability value is less than 0.05 , a $5 \%$ significant result will be detected. 
b. If P-Value (probability value is greater than or equal to 0.05 , the non-significant result will be declared.

\section{Test Criteria}

The test criteria were performed using the "Fisher's F" test, which was compared with the corresponding tabular value of the "Fisher's F" Distribution.

\section{Variance Analysis}

The data obtained on the number and size of the active shoots of the living twigs at 45 days of the rooting process were calculated in the SPSS statistical program, the results obtained are shown in (Table 2). Analysis of variance of the completely randomized design with the same number of observations of the number and size of the active shoots of the live national cacao twigs 45 days after the rooting process inside vacuum bags.

\section{Decision:}

a) If P-Value (probability value is less than 0.05 , a $5 \%$ significant result will be detected.

b) If P-Value (probability value is greater than or equal to 0.05 , the non-significant result will be declared. The significance level to be used is: $\alpha=0.05$ (95\% confidence).

\section{Statistical Procedure}

\section{1) Multiple range test}

The Comparison of means was carried out using the Tukey test at $95 \%$ confidence, to differentiate between pairs of means after the null hypothesis is rejected in the analysis of variance.

\section{2) Design Features}

Because only a single factor was evaluated, which is the efficiency of the hormones that was applied in each of the treatments, a completely randomized design was developed with 6 treatments, equal number of repetitions and equal number of experimental sample units. said design had the following characteristics:
Treatments: 6

Repeat by treatment: 5 .

Plants by repetition:10

No. plants per treatments: fifty

Number of plants per test: 300

\section{Results and Discussions}

\section{Efficiency of The Hormones Used in The Rooting of The Cacao Branches of National Type Clon Ett-48 At 45 Days of The Rooting Process}

Number of live twigs 45 days after the rooting process (Figure 1) according to the results obtained, in the ANOVA table there is a significant difference between treatments (Index Table 1), indicating that T3 (29 live twigs) and T5 (26 live twigs) showed significant values with $\mathrm{T} 1, \mathrm{~T} 2, \mathrm{~T} 4$ and $\mathrm{T} 6$. The $\mathrm{T} 3$ results can be credited to what [37]. point out that the hormone most used to spread asexually is auxin while [36] indicate that the use of powders Auxin-based rooting agents has given good results in woody plants. The T5 results obtained are based on what was mentioned by [20] mention that it has a series of solutions including auxin and cytokinin growth regulators, amino acids such as glycine, glutamic acid and tryptophan that serve for the synthesis of auxins. The twigs were subjected to shade with the passage of $10 \%$ light to control the light intensity and the temperature within the test which comprised between $26^{\circ} \mathrm{C}$ and $32^{\circ} \mathrm{C}$, with a relative humidity of $95 \%$ inside vacuum covers,

Index Table 1: ANOVA, for the number of live twigs of national cacao 45 days after the greenhouse trial.

\begin{tabular}{|c|c|c|c|c|c|}
\hline \multicolumn{2}{|c|}{ Sum of squares } & gl & Quadratic mean & F & S.I.G. \\
\hline Between groups & 94,300 & 5 & 18.86 & 11,316 & 0 \\
\hline Within groups & 40 & 24 & 1,667 & & \\
\hline Total & 134.3 & 29 & & & \\
\hline
\end{tabular}

Note: 95.0 percentage Tukey method Significant difference between treatments $(\alpha<0.05)$

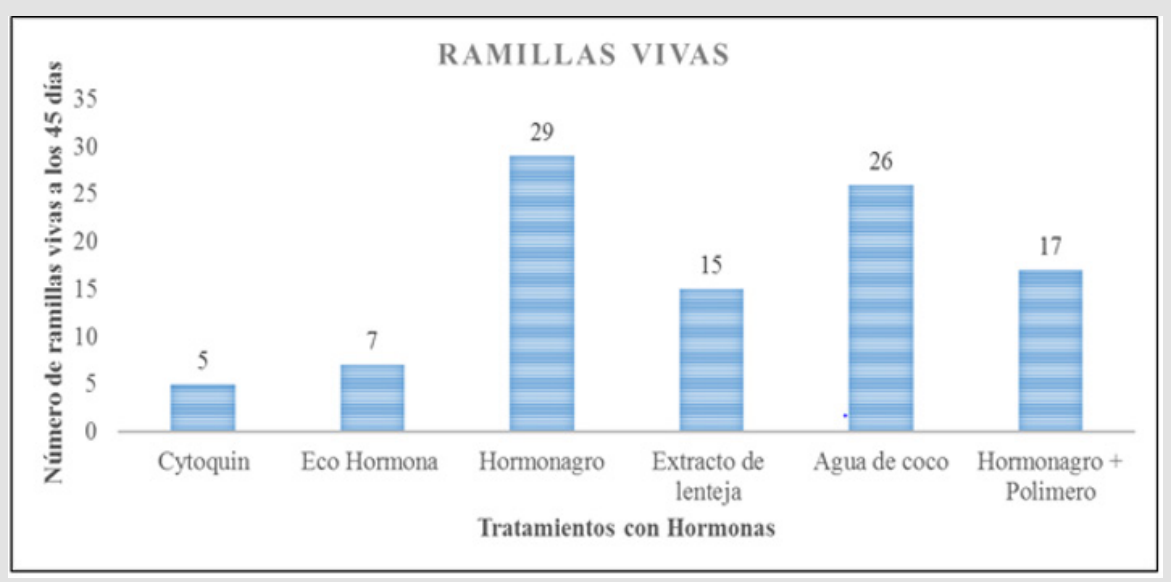

Figure 1: Number of live twigs 45 days after the rooting process with the different hormones used. 
All the controlled conditions in the experimental trial for the survival of the twigs are argued in what is stated by [29] indicates that the place of propagation must have light conditions less than $25 \%$, [31] points out that the humidity relative where the twigs should develop has to be between 90 and 100\% while Lira, pressure that allows it to absorb water slowly and steadily, filling the empty xylem vessels which have lost water. Rooting percentage of national type cocoa twigs with the different treatments (Figure 2) shows the efficiency of the hormones used, according to the results obtained there is a significant difference between treatments (Table 1), indicating that the T3 (58\%) and T5 (52\%) of rooting were the treatments that obtained the highest number of live twigs (Figure 1) which obtained significant values compared to treatments $T 1$ (10\%), T2 (14\%), T4 (30\%) and T6 (34\%). Average of the number of live twigs in 45 days started the rooting process (Figure 3), the efficiency of the treatments in the twigs of national type cocoa in its results, an analysis of variance was performed to establish a difference between the mean of the treatments evaluated.

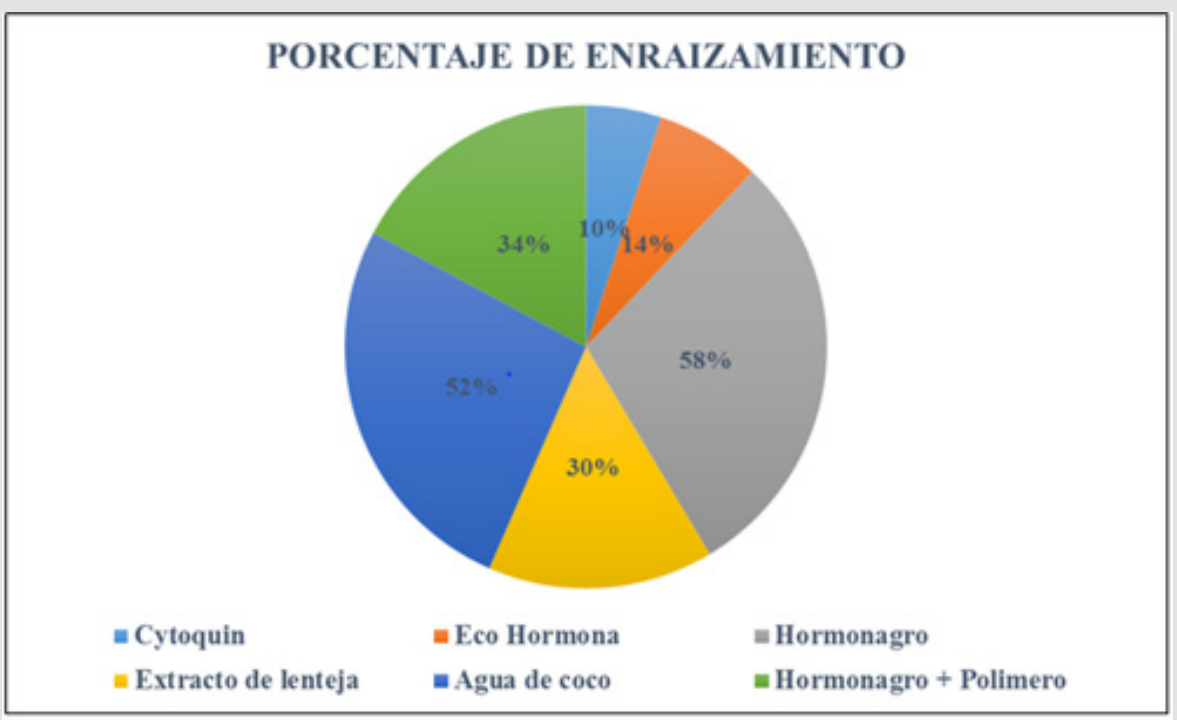

Figure 2: Rooting percentage of national type cocoa clone ETT-48 twigs with the different hormones used.

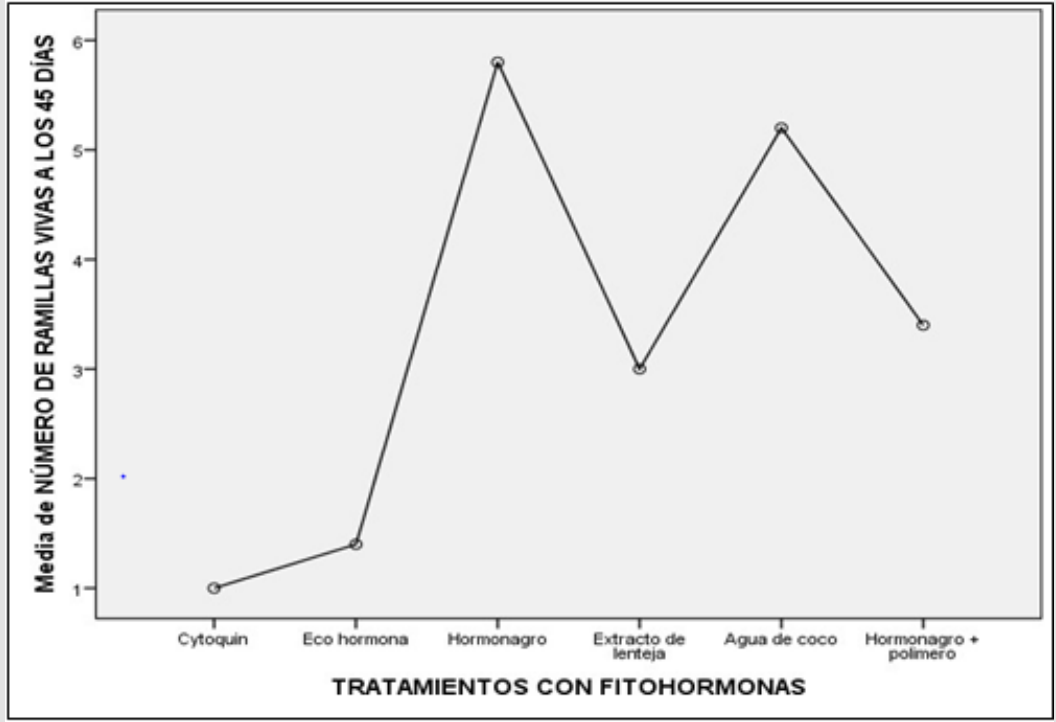

Figure 3: Average number of live twigs of national poop 45 days after the rooting process.

The alpha value less than 0.05 , therefore it is determined that there was a significant difference in the mean of at least one treatment (Table 1), the null hypothesis is rejected, the means of T3 (5.80) and T5 are observed (5.20) being the highest values, this indicates significant differences between the mean of the evaluated treatments, T1 (1.00), T2 (1.40), T4 (3.00) and T6 (3.40) (Index Table 2). Calculation of the ANOVA table for the number of live twigs of national type cocoa clone ETT -48 at 45 in a greenhouse under shade (Table 1), showed that the value of alpha $(\alpha) 0.000$ is less than 0.05 which indicates that there is a significant difference 
between treatments, therefore the mean of one of them is different from the mean of the rest. The test of the significant differences of the means between treatments for the number of live twigs of national cocoa clone ETT-48 at 45 days of the trial (Table 2), indicates that $\mathrm{T} 3$ and $\mathrm{T} 5$ obtained the highest number of live twigs (Figure 1) in the multiple comparisons between treatments proved to be significant with T1, T2 and T4, for T6 they showed a lower significance [40-42].

Table 1: Treatments and repetitions with the different growth hormones that were applied to the national type of cocoa twigs of the ETT-48 clone, the same ones that were developed under a greenhouse inside a chamber with zaran and inside vacuum covers at the Farm Holy Ines.

\begin{tabular}{|c|c|c|c|}
\hline No. repetitions & Treatments & Code & Hormone application to base of twigs \\
\hline 5 & T1 & T1R1, T1R2, T1R3, T1R4, T1R5 & Immersed in cytokin \\
\hline 5 & T2 & T2R1, T2R2, T2R3, T2R4, T2R5 & Dipped in echo hormone \\
\hline 5 & T3 & T3R1, T3R2, T3R3, T3R4, T3R5 & Sprinkle with greasy hormone Dipped in lentil extract \\
\hline 5 & T4 & T4R1, T4R2, T4R3, T4R4, T4R5 & Dipped in tender coconut water \\
\hline 5 & T5 & T5R1, T5R2, T5R3, T5R4, T5R5 & Sprinkle with greasy hormone \\
\hline 5 & T6 & T6R1, T6R2, T6R3, T6R4, T6R5 & + polymer to substrate \\
\hline
\end{tabular}

Table 2: Analysis of variance of the completely randomized design with the same number of observations of the number and size of the active shoots of the live national cacao twigs 45 days after the rooting process inside vacuum bags.

\begin{tabular}{|c|c|c|c|c|c|}
\hline Number of & Sum of & gl & Half & F & S.I.G. \\
\hline live twigs & squares & & Quadratic & & \\
\hline Between groups & 94,300 & 5 & 18.86 & 11,316 & 0 \\
\hline Size of & Sum of & gl & Half & F & S.I.G. \\
\hline active sprouts & squares & & Quadratic & & \\
\hline Between groups & $2,930,252$ & 5 & 586,050 & 7,827 & 0 \\
\hline
\end{tabular}

Index Table 2: Test of the significant differences of the means between treatments for the number of live twigs of national cocoa clone ETT-48 at 45 days of the trial.

\begin{tabular}{|c|c|c|}
\hline Treatments & Socks & Homogeneous Groups \\
\hline T1 Cytoquin & 1 & TO \\
\hline T2 Eco Hormones & 1.4 & TO \\
\hline T3 Hormonegro & 5.8 & BC \\
\hline T4 Lentil Extract & 3 & AC \\
\hline T5 Coconut water Tender & 5.2 & BC \\
\hline T6 Hormonagro + Polymer & 3.4 & ABC \\
\hline
\end{tabular}

Note: 95.0 percentage Tukey method Stockings with a common letter are not significantly different

\section{Efficiency of Hormones in The Development of National Type Cacao Branches Clone Ett-48 At 45 Days of The Rooting Process}

It shows the development of the shoots in the twigs with the different hormones used (Figure 4), according to the results obtained, T2 presented shoots between 6 and 30 millimeters (Annex 2) and a higher number per twig (Figures $5 \& 6$ ) between treatments , T3 showed few shoots in development and number (Figure 7) despite having a greater number of live twigs between the different treatments (Figure 1), T5 showed a large number of live twigs and shoots, showed uniformity with a single shoot per branch (Figure 9) and their development between 4 and 33 millimeters of growth (Annex 2). The results obtained in T2 showed greater sprouting in its twigs and because it is a tri-hormonal product, it is argued in what is mentioned by Lira. It indicates the number of active shoots of the live twigs at 45 days in T1 (Figure 5), according to the results obtained in its five living twigs, it showed uniformity of its active shoots one per twig.

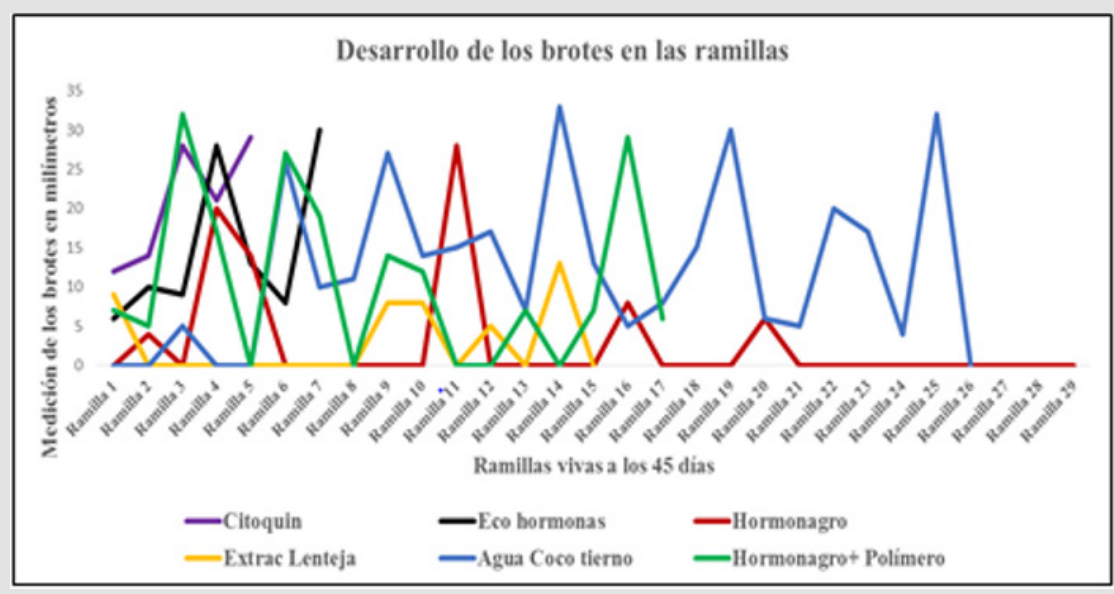

Figure 4: Development of the shoots in the twigs with the different hormones used. 


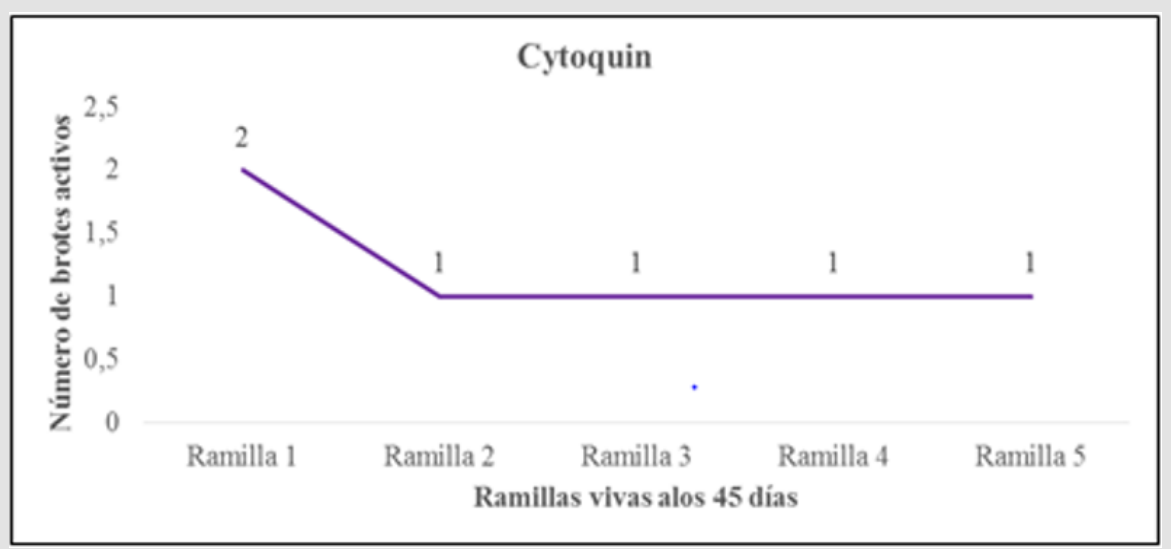

Figure 5: Number of active shoots of live twigs at 45 days in T1.

It indicates the number of active shoots of the live twigs at 45 days in T2 (Figure 6), in its seven living twigs a difference of two to three shoots per twig was shown, being the treatment that had the highest number of active shoots per twig presented. It indicates the number of active shoots of the live twigs at 45 days in T3 (Figure 7), the results show few active shoots despite having a greater number of live twigs (one shoot per twig). It shows the number of active shoots of the live twigs at 45 days in T4 (Figure 8), the results showed few active shoots in its 15 live twigs. It indicates the number of active shoots of the live twigs at 45 days in T5 (Figure 9), the results indicate in its 26 live twigs a uniformity of an active bud in most of the twigs. It shows the number of active shoots of the living twigs at 45 days in T6 (Figure 10), the results showed in its 17 living twigs the presence of a single bud per twig in most of them. It indicates the means of the development of the shoots in millimeters of the live twigs of national cocoa clone ETT -48 at 45 days of the rooting process (Figure 11).

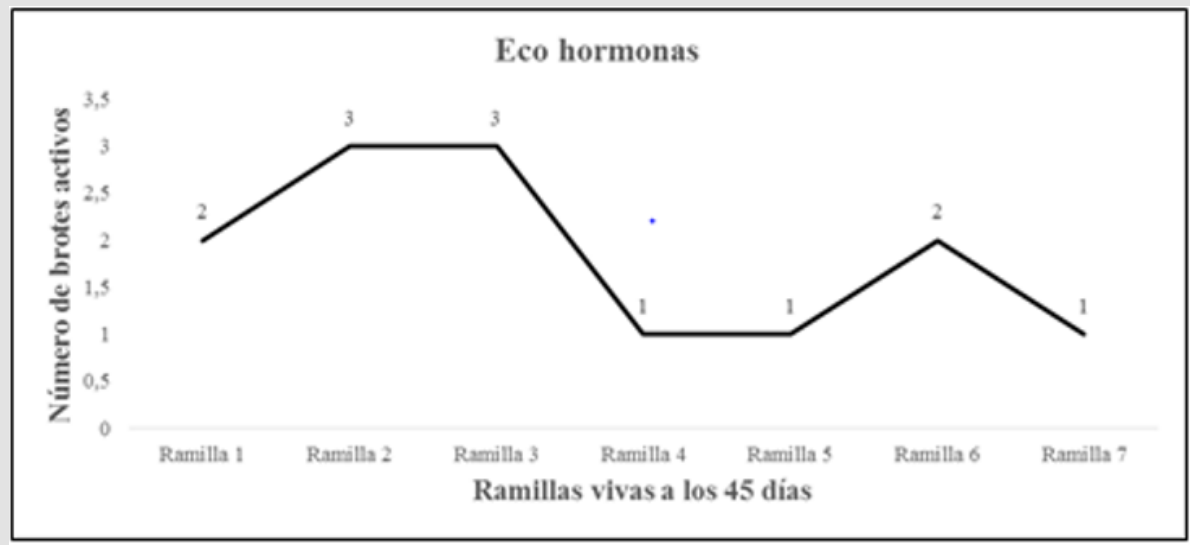

Figure 6: Number of active shoots of living twigs at 45 days in T2.

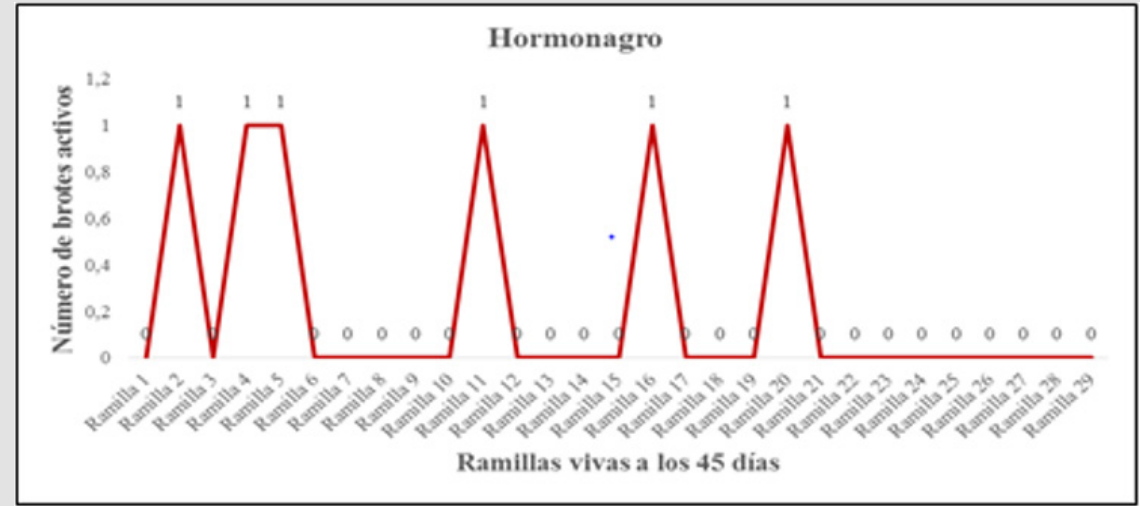

Figure 7: Number of active shoots of the living twigs at 45 days in T3. 


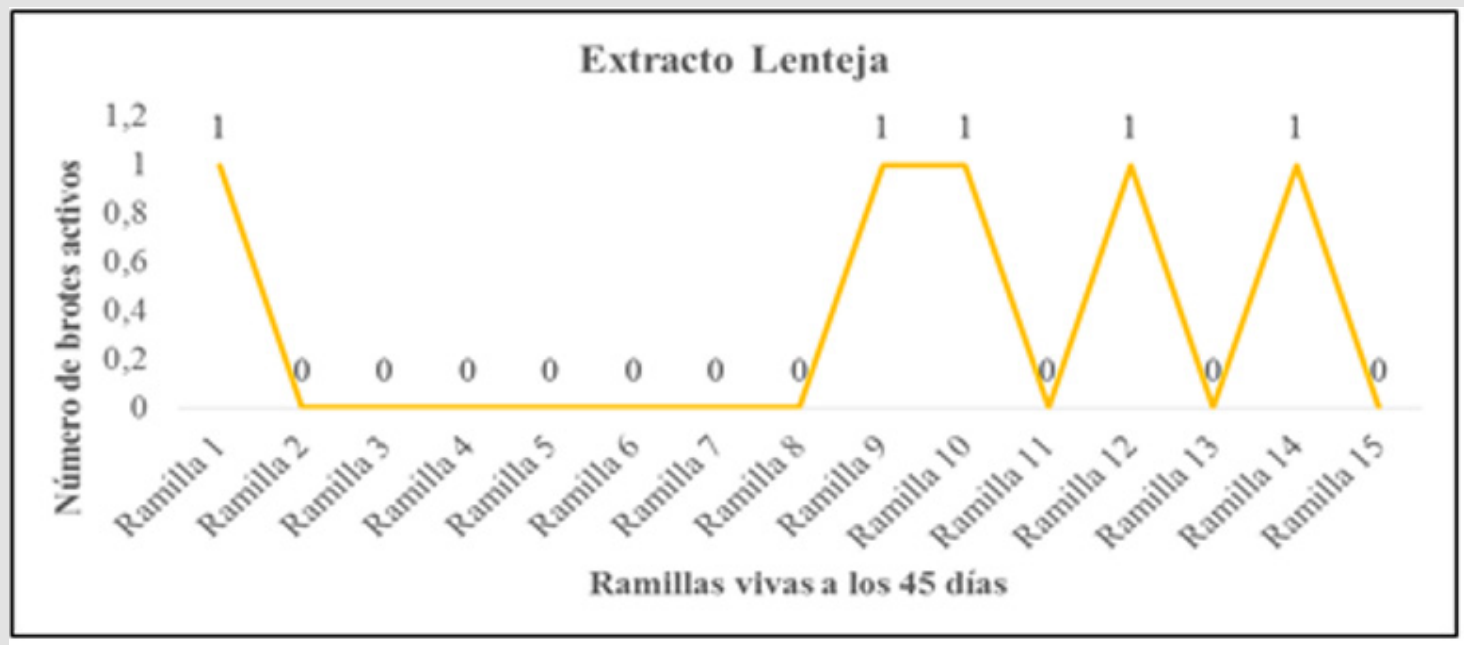

Figure 8: Number of active shoots of the living twigs at 45 days in T4.

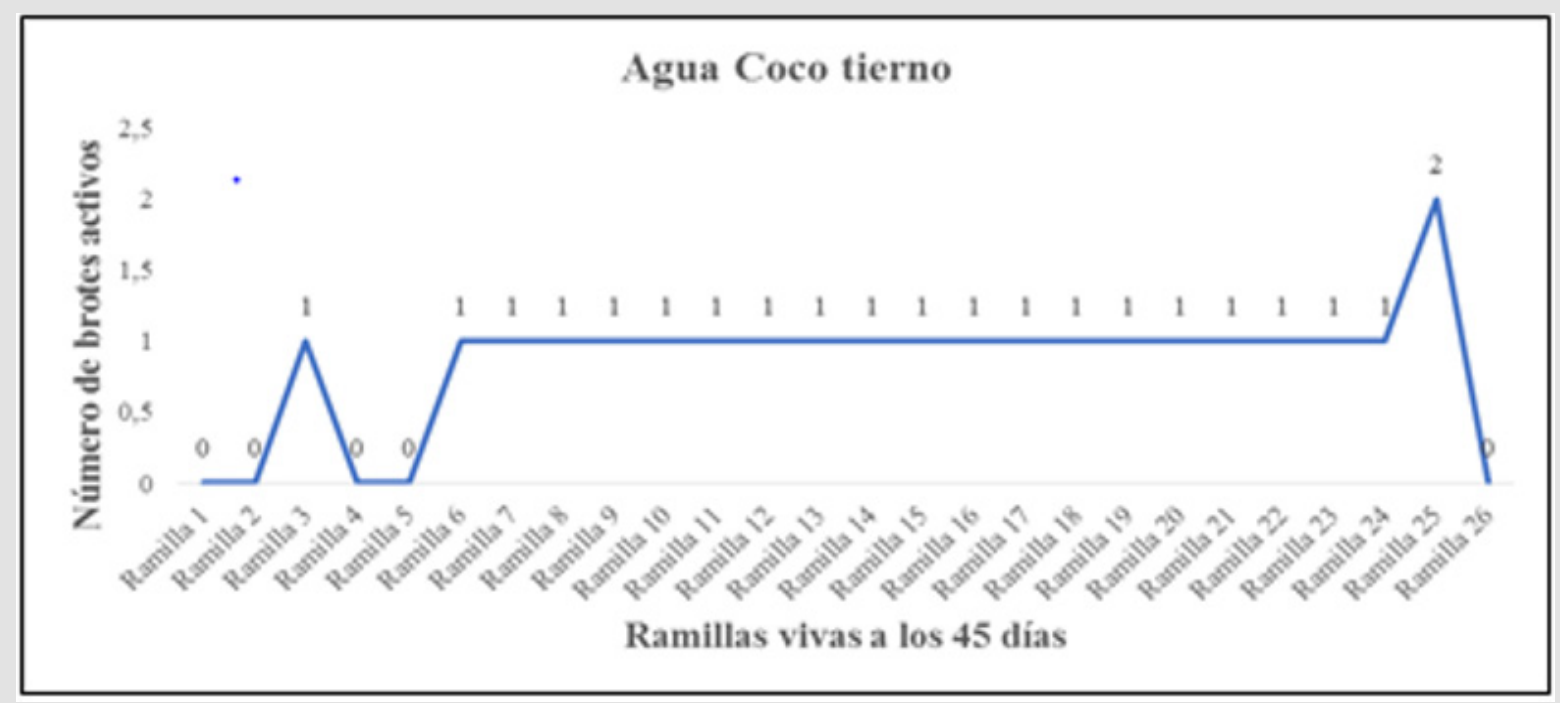

Figure 9: Number of active shoots of the living twigs at 45 days in T5.

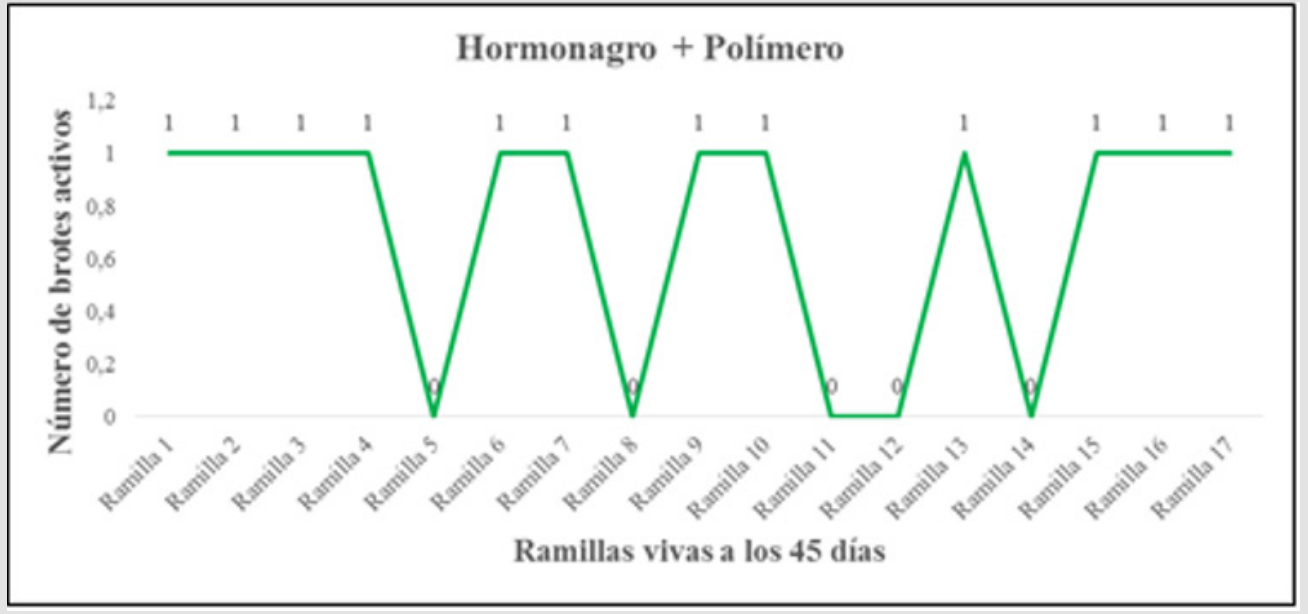

Figure 10: Number of active shoots of the living twigs at 45 days in T6. 


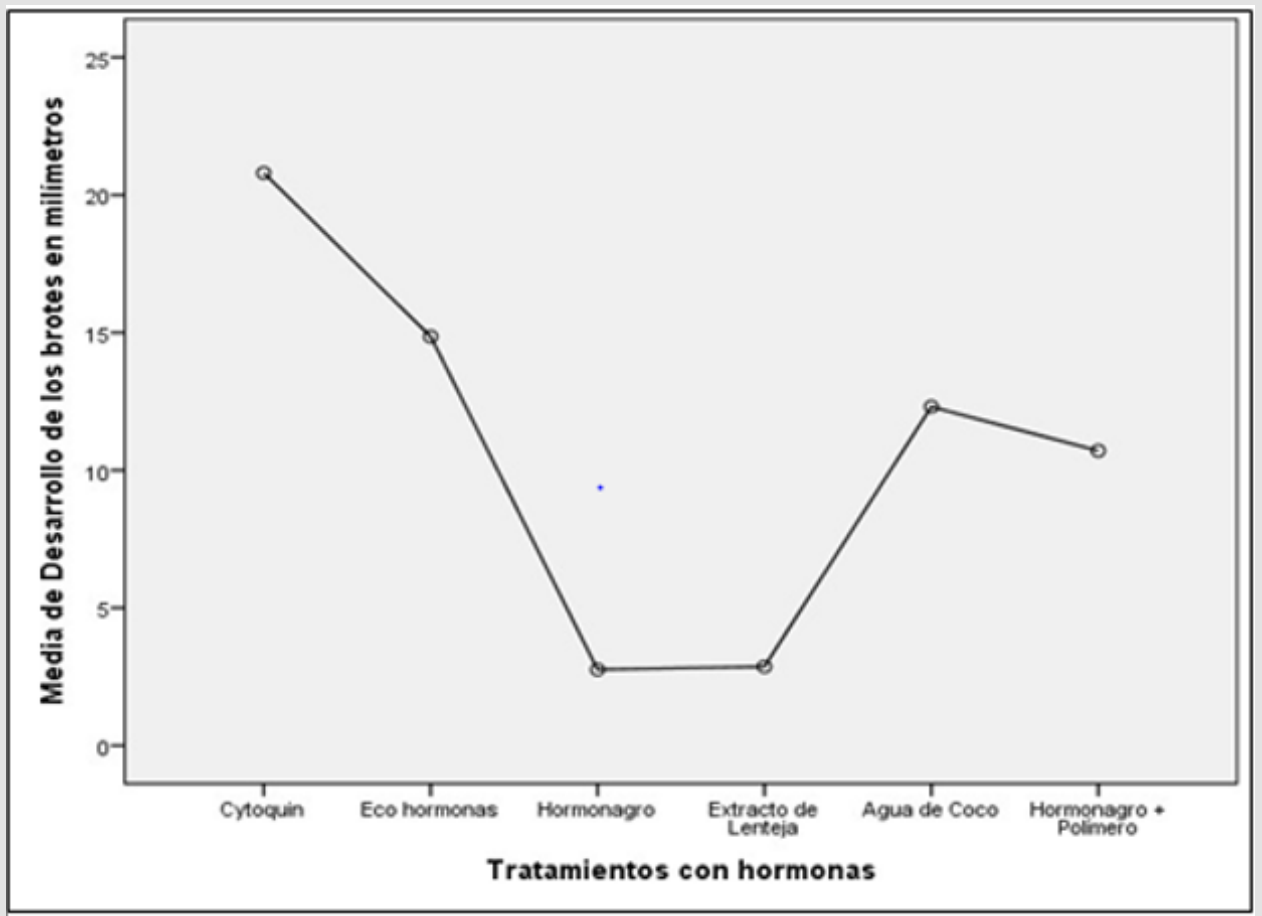

Figure 11: Means of shoot development in millimeters of live twigs of national cocoa clone ETT -48 at 45 days of the rooting process.

The efficiency of the treatments demonstrated by an analysis of variance a difference between the treatments evaluated showing an alpha value less than 0.05 , it was determined that there was a significant difference in the mean of at least one treatment (Index Table 3), it is observed that the means of T1 (20.80) and T2 (14.86) were the highest and Through multiple comparisons between treatment. It was determined that T5 (12.31), T6 (10.71) were significant with the other treatments to a lesser degree and more significant for T3 (2.76) and T4 (2.87) (Index Table 4). Calculation of the ANOVA table for the development of the shoots in millimeters of the live twigs of national type cocoa clone ETT - 48 at 45 of the rooting process (Table 3 ), which showed that the value of alpha ( $\alpha$ ) 0.000 is less than 0.05 , it indicates that there is a significant difference between treatments, at least the mean of one of them is different from the mean of the rest.

Index Table 3: ANOVA, for the development of the shoots in millimeters of the live twigs of national type cocoa clone ETT -48 at 45 of the rooting process.

\begin{tabular}{|c|c|c|c|c|c|}
\hline \multicolumn{2}{|c|}{ Sum of squares } & gl & Quadratic mean & F & S.I.G. \\
\hline Between groups & $2,930,252$ & 5 & 586,050 & 7,827 & 0 \\
\hline Within groups & $6,963,769$ & 93 & 74,879 & & \\
\hline Total & $9,894,020$ & 98 & & & \\
\hline
\end{tabular}

Note: 95.0 percentage Tukey method Significant difference between treatments $(\alpha<0.05)$
Index Table 4: Test of the significant differences of the means between treatments for the development of the shoots of the living twigs at 45 days of the rooting process.

\begin{tabular}{|c|c|c|}
\hline Treatments & Socks & Homogeneous Groups \\
\hline T1 Cytoquin & 20.8 & TO \\
\hline T2 Eco Hormones & 14.86 & TO \\
\hline T3 Hormonegro & 2.76 & B \\
\hline T4 Lentil Extract & 2.87 & BC \\
\hline T5 Coconut water Tender & 12.31 & TO \\
\hline T6 Hormonagro + Polymer & 10.71 & AC \\
\hline
\end{tabular}

Note: 95.0 percentage Tukey method Stockings with a common letter are not significantly different

The significant differences between the treatments in the development of the shoots of the live twigs at 45 days of the rooting process (Table 4), indicates the $\mathrm{T} 1$ in addition to presenting a lower number of live twigs (Figure 11), it presented a greater development of the shoots at 45 days of the rooting process as well as the T2 but in less growth (Figure 4), which compared to T3, T4, T5 and T6 were significant.

\section{Conclusion}

1. The Efficiency of the commercial hormones showed rooting percentages in the national-type cocoa twigs at 45 days, $58 \%$ was the highest corresponding to T3, followed by T2 14\% and $\mathrm{T} 1$ 10\% that presented the lowest percentages. The T3 results are supported by research showing that products such 
as auxin-based rooting powders have given good results in the survival of woody plants that have been propagated by different asexual methods.

2. The Efficiency of the hormones of natural synthesis showed rooting percentages in the branches of national type cocoa at 45 days, the $\mathrm{T} 5$ presented a high percentage of rooting of $52 \%$, attributing its efficiency, the liquid endosperm of the coconut is composed of growth regulating hormones and amino acids that allow the branches to develop the root system and new aerial tissues, T4 presented a rooting percentage of $30 \%$.
The Efficiency of commercial hormones and natural synthesis showed development in the shoots of the national-type cocoa twigs 45 days after the rooting process, $\mathrm{T} 1$ presented greater development of shoots because the product promotes the development of buds, T2 was the treatment that presented the highest number of active shoots per branch, is a tri-hormonal physiological activator product, T5 showed a large number of branches and uniformity of sprouting, tender coconut water has amino acids for the synthesis of auxins, it also contains cytokinins with those that interact for the formation of new tissues (Annex Tables 1-5).

Annex Table 1: Number from Live twigs of national cocoa clone ETT - 48 by treatment and development of the shoots in millimeters at 45 days after the rooting process.

\begin{tabular}{|c|c|c|c|c|c|c|}
\hline \multicolumn{7}{|c|}{ Number Of Twigs Per Treatment And Shoot Development In Millimeters } \\
\hline No. Twig & Cytoqui n & Echo hormones & Hormone & Lentil Extract & Tender coconut water & Hormonagro \\
\hline Branch 1 & 12 & 6 & 0 & 9 & 0 & 7 \\
\hline Branch 2 & 14 & 10 & 4 & 0 & 0 & 5 \\
\hline Branch 3 & 28 & 9 & 0 & 0 & 5 & 32 \\
\hline Branch 4 & twenty-one & 28 & twenty & 0 & 0 & 17 \\
\hline Branch 5 & 29 & 13 & 14 & 0 & 0 & 0 \\
\hline Branch 6 & & 8 & 0 & 0 & 26 & 27 \\
\hline Branch 7 & & 30 & 0 & 0 & 10 & 19 \\
\hline Branch 8 & & & 0 & 0 & eleven & 0 \\
\hline Branch 9 & & & 0 & 8 & 27 & 14 \\
\hline Twig 10 & & & 0 & 8 & 14 & 12 \\
\hline Twig eleven & & & 28 & 0 & fifteen & 0 \\
\hline Twig 12 & & & 0 & 5 & 17 & 0 \\
\hline Twig 13 & & & 0 & 0 & 7 & 7 \\
\hline Twig 14 & & & 0 & 13 & 33 & 0 \\
\hline Twig fifteen & & & 0 & 0 & 13 & 7 \\
\hline Twig 16 & & & 8 & & 5 & 29 \\
\hline Twig 17 & & & 0 & & 8 & 6 \\
\hline Twig 18 & & & 0 & & fifteen & \\
\hline Twig 19 & & & 0 & & 30 & \\
\hline Twig twenty & & & 6 & & 6 & \\
\hline Twig twenty-one & & & 0 & & 5 & \\
\hline Twig 22 & & & 0 & & twenty & \\
\hline Twig 23 & & & 0 & & 17 & \\
\hline Twig 24 & & & 0 & & 4 & \\
\hline Twig 25 & & & 0 & & 32 & \\
\hline
\end{tabular}

Annex Table 2: Descriptive analysis, number of live twigs of national cocoa clone ETT-48 after 45 days of initiating the rooting process. Calculation of the results in SPSS statistical software. Number of live twigs at 50 days.

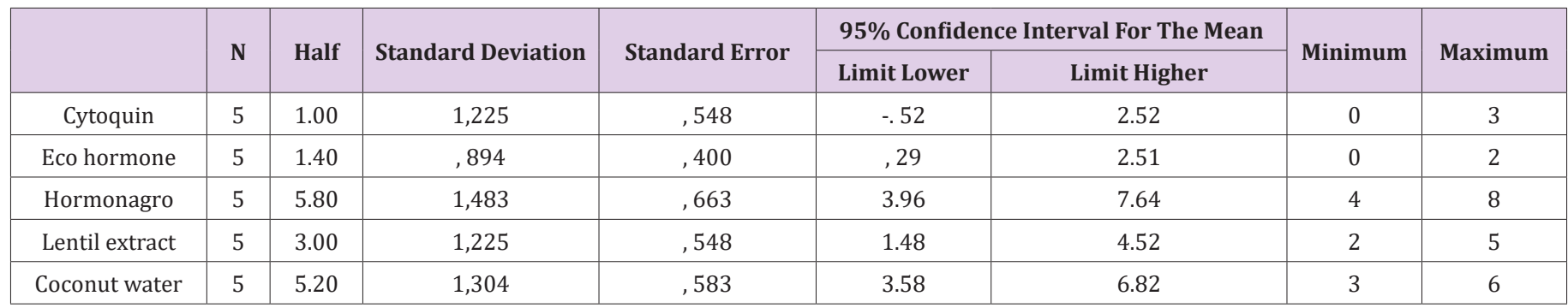




\begin{tabular}{|c|c|c|c|c|c|c|c|c|}
\hline $\begin{array}{c}\text { Hormonagro }+ \\
\text { polymer }\end{array}$ & 5 & 3.40 & 1,517 &, 678 & 1.52 & 5.28 & 5 \\
\hline Total & 30 & 3.30 & 2,152 &, 393 & 2.50 & 4.10 & 0 & 8 \\
\hline
\end{tabular}

Number of live twigs at 50 days

Significance level 0.05 Tukey

Annex Table 3: Multiple comparisons, difference and significance between the means of the 6 treatments used in the rooting of the shoots of national type cocoa clone ETT-48. Calculation of the results in SPSS statistical software.

Multiple comparisons Dependent variable: number of twigs alive at 50 days HSD. Tukey: The mean difference is significant at the 0.05 level, Tukey.

\begin{tabular}{|c|c|c|c|c|c|c|}
\hline \multirow{2}{*}{$\begin{array}{l}\text { (I) Treatments With } \\
\text { Phytohormones }\end{array}$} & \multirow{2}{*}{$\begin{array}{l}\text { (J) Treatments With } \\
\text { Phytohormones }\end{array}$} & \multirow{2}{*}{ Difference Of Means (IJ) } & \multirow{2}{*}{$\begin{array}{l}\text { Standard } \\
\text { Error }\end{array}$} & \multirow{2}{*}{ S.I.G. } & \multicolumn{2}{|c|}{ 95\% Interval Trust } \\
\hline & & & & & Lower Limit & Upper Limit \\
\hline \multirow[t]{5}{*}{ Cytoquin } & Eco hormone &,- 400 &, 816 & .996 & -2.92 & 2.12 \\
\hline & Hormonagro & $-4,800 *$ & 816 &, 000 & -7.32 & -2.28 \\
\hline & Lentil extract & $-2,000$ & 816 & 179 & -4.52 &, 52 \\
\hline & Coconut water & $-4,200 *$ &, 816 &, 000 & -6.72 & -1.68 \\
\hline & Hormonagro + polymer & $-2,400$ & 816 & .069 & -4.92 &, 12 \\
\hline \multirow[t]{5}{*}{ Eco hormone } & Cytoquin &, 400 &, 816 & .996 & -2.12 & 2.92 \\
\hline & Hormonagro & $-4,400 *$ &, 816 &, 000 & -6.92 & -1.88 \\
\hline & Lentil extract & $-1,600$ & 816 &, 393 & -4.12 &, 92 \\
\hline & Coconut water & $-3,800 *$ &, 816 &, 001 & -6.32 & -1.28 \\
\hline & Hormonagro + polymer & $-2,000$ & 816 & 179 & -4.52 &, 52 \\
\hline \multirow[t]{5}{*}{ Hormonagro } & Cytoquin & $4,800 *$ &, 816 &, 000 & 2.28 & 7.32 \\
\hline & Eco hormone & $4,400^{*}$ & 816 &, 000 & 1.88 & 6.92 \\
\hline & Lentil extract & $2,800^{*}$ & 816 & .024 & 28 & 5.32 \\
\hline & Coconut water &, 600 & 816 & , 975 & -1.92 & 3.12 \\
\hline & Hormonagro + polymer & 2,400 & , 816 & .069 &,- 12 & 4.92 \\
\hline \multirow[t]{5}{*}{ Lentil extract } & Cytoquin & 2,000 &, 816 &, 179 & -.52 & 4.52 \\
\hline & Eco hormone & 1,600 & 816 &, 393 & -.92 & 4.12 \\
\hline & Hormonagro & $-2,800 *$ &, 816 & .024 & -5.32 &,- 28 \\
\hline & Coconut water & $-2,200$ & 816 & , 113 & -4.72 & 32 \\
\hline & Hormonagro + polymer &,- 400 &, 816 & .996 & -2.92 & 2.12 \\
\hline \multirow[t]{5}{*}{ Coconut water } & Cytoquin & $4,200^{*}$ &, 816 &, 000 & 1.68 & 6.72 \\
\hline & Eco hormone & $3,800 *$ &, 816 &, 001 & 1.28 & 6.32 \\
\hline & Hormonagro &,- 600 &, 816 &, 975 & -3.12 & 1.92 \\
\hline & Lentil extract & 2,200 & 816 & , 113 &,- 32 & 4.72 \\
\hline & Hormonagro + polymer & 1,800 &, 816 &, 272 & -.72 & 4.32 \\
\hline \multirow[t]{5}{*}{ Hormonagro + polymer } & Cytoquin & 2,400 &, 816 & .069 &,- 12 & 4.92 \\
\hline & Eco hormone & 2,000 &, 816 &, 179 & -.52 & 4.52 \\
\hline & Hormonagro & $-2,400$ &, 816 & .069 & -4.92 &, 12 \\
\hline & Lentil extract &, 400 &, 816 & .996 & -2.12 & 2.92 \\
\hline & Coconut water & $-1,800$ &, 816 & 272 & -4.32 &, 72 \\
\hline
\end{tabular}

Dependent variable: number of twigs alive at 50 days HSD Tukey: The mean difference is significant at the 0.05 level, Tukey.

Annex Table 4: Descriptive analysis, development of the shoots in millimeters of the live twigs of national cocoa clone ETT-48 after 45 days of initiating the rooting process. Calculation of the results in SPSS statistical software. Shoot development in millimeters.

\begin{tabular}{|c|c|c|c|c|c|c|c|c|c|}
\hline $\begin{array}{c}\text { Hormone } \\
\text { Treatments }\end{array}$ & Half & N & Dev. Typ. & Median & Sum & Maximum & Minimum & Rank & Varianz To \\
\hline Cytoquin & 20.80 & 5 & 7,791 & 21.00 & 104 & 29 & 12 & 17 & 60,700 \\
\hline Echo hormones & 14.86 & 7 & 9,907 & 10.00 & 104 & 30 & 6 & 24 & 98,143 \\
\hline
\end{tabular}




\begin{tabular}{|c|c|c|c|c|c|c|c|c|c|}
\hline Hormonagro & 2.76 & 29 & 6,749 &, 00 & 80 & 28 & 0 & 28 & 45,547 \\
\hline Lentil extract & 2.87 & fifteen & 4,470 &, 00 & 43 & 13 & 0 & 13 & 19,981 \\
\hline Coconut water & 12.31 & 26 & 10,457 & 10.50 & 320 & 33 & 0 & 33 & 109,342 \\
\hline $\begin{array}{c}\text { Hormonagro } \\
\text { Polymer }\end{array}$ & 10.71 & 17 & 10,734 & 7.00 & 182 & 32 & 0 & 32 & 115,221 \\
\hline Total & 8.41 & 99 & 10,048 & 5.00 & 833 & 33 & 0 & 33 & 100,959 \\
\hline
\end{tabular}

Shoot development in millimeters

Annex Table 5: Multiple comparisons, difference and significance between the means of the 6 treatments used in the development of the shoots in millimeters of the national type ETT-48 clone cacao twigs. Calculation of the results in SPSS statistical software. Dependent variable: Shoot development in millimeters Tukey's HSD: The difference in means is significant at the 0.05 level.

\begin{tabular}{|c|c|c|c|c|c|c|}
\hline \multirow{2}{*}{$\begin{array}{l}\text { (I) Hormone } \\
\text { Treatments }\end{array}$} & \multirow{2}{*}{ (J) Hormone Treatments } & \multirow{2}{*}{ Difference Of Means (IJ) } & \multirow{2}{*}{ Typical Error } & \multirow{2}{*}{ S.I.G. } & \multicolumn{2}{|c|}{ 95\% Confidence Interval } \\
\hline & & & & & Lower Limit & Upper Limit \\
\hline & Echo hormones & 5,943 & 5,067 &, 849 & -8.80 & 20.69 \\
\hline & Hormonagro & $18.041 *$ & 4,190 &, 001 & 5.85 & 30.23 \\
\hline \multirow[t]{5}{*}{ Cytoquin } & Lentil extract & $17,933 *$ & 4,469 &, 002 & 4.93 & 30.94 \\
\hline & Coconut water & 8,492 & 4,226 & ,3.4.5 & -3.80 & 20.79 \\
\hline & Hormonagro + Polymer & 10,094 & 4,402 &, 207 & -2.72 & 22.90 \\
\hline & Cytoquin & $-5,943$ & 5,067 &, 849 & -20.69 & 8.80 \\
\hline & Hormonagro & $12,099 *$ & 3,644 & .016 & 1.49 & 22.70 \\
\hline \multirow[t]{5}{*}{ Echo hormones } & Lentil extract & $11,990 *$ & 3,961 & .037 &, 46 & 23.52 \\
\hline & Coconut water & 2,549 & 3,685 &, 982 & -8.17 & 13.27 \\
\hline & Hormonagro + Polymer & 4,151 & 3,886 &, 893 & -7.16 & 15.46 \\
\hline & Cytoquin & $-18.041 *$ & 4,190 &, 001 & -30.23 & -5.85 \\
\hline & Echo hormones & $-12,099 *$ & 3,644 & .016 & -22.70 & -1.49 \\
\hline \multirow[t]{5}{*}{ Hormonagro } & Lentil extract &,- 108 & 2,752 & 1,000 & -8.12 & 7.90 \\
\hline & Coconut water & $-9.549 *$ & 2,337 &, 001 & -16.35 & -2.75 \\
\hline & Hormonagro + Polymer & $-7.947 *$ & 2,643 & .039 & -15.64 &,- 26 \\
\hline & Cytoquin & $-17,933 *$ & 4,469 &, 002 & -30.94 & -4.93 \\
\hline & Echo hormones & $-11,990 *$ & 3,961 & .037 & -23.52 & -.46 \\
\hline \multirow[t]{5}{*}{ Lentil extract } & Hormonagro &, 108 & 2,752 & 1,000 & -7.90 & 8.12 \\
\hline & Coconut water & $-9,441 *$ & 2,806 & .014 & -17.61 & -1.28 \\
\hline & Hormonagro + Polymer & $-7,839$ & 3,065 &, 119 & -16.76 & 1.08 \\
\hline & Cytoquin & $-8,492$ & 4,226 & ,3.4.5 & -20.79 & 3.80 \\
\hline & Echo hormones & $-2,549$ & 3,685 &, 982 & -13.27 & 8.17 \\
\hline \multirow[t]{5}{*}{ Coconut water } & Hormonagro & $9.549 *$ & 2,337 &, 001 & 2.75 & 16.35 \\
\hline & Lentil extract & $9.441 *$ & 2,806 & .014 & 1.28 & 17.61 \\
\hline & Hormonagro + Polymer & 1,602 & 2,699 & .991 & -6.25 & 9.46 \\
\hline & Cytoquin & $-10,094$ & 4,402 &, 207 & -22.90 & 2.72 \\
\hline & Echo hormones & $-4,151$ & 3,886 &, 893 & -15.46 & 7.16 \\
\hline \multirow[t]{3}{*}{ Hormonagro + Polymer } & Hormonagro & $7,947 *$ & 2,643 & .039 &, 26 & 15.64 \\
\hline & Lentil extract & 7,839 & 3,065 &, 119 & -1.08 & 16.76 \\
\hline & Coconut water & $-1,602$ & 2,699 & .991 & -9.46 & 6.25 \\
\hline
\end{tabular}

Dependent variable: Shoot development in millimeters Tukey's HSD: The difference in means is significant at the 0.05 level. 


\section{Recommendation}

1. Use a balanced substrate between soil, sand and organic matter, sterilized prior to planting the twigs.

2. Avoid any means of contamination when harvesting the twigs.

3. Not having the twigs unseeded for a long time due to their dehydration.

4. Consider when planting the twigs that the substrate must be at field capacity, excess water causes problems of twig rot

5. The The shadow to which the twigs must be in layers and allow $10 \%$ of light to pass through, a factor that must be gradually graduated.

6. Have an infrastructure that ensures optimal environmental humidity greater than $80 \%$ and a percentage of light of the passage of $10 \%$ to avoid dehydration of the twigs after extracting them from the covers the vacuum because it causes their death.

7. The elite plants selected when they are in the flowering season, remove the flowers and perform a pruning to ensure that the plant emits new shoots, and all the reserves are used in their development.

\section{References}

1. Ramírez M (2013) Effect of organic fertilizers on the cultivation of Theobroma cacao L. in the nursery of the "Recinto el Capricho", Napo Province, Ecuador. Amazonian Science and Technology Magazine 2(1): 31-40.

2. Ruales M (2013) Origin and aroma of Ecuadorian cocoa. 1 Ed. Quito, Ecuador. Agrocality pp. 31-34.

3. (2011) Sectoral Analysis of Cacao and Processed Ecuador p. 3-4.

4. Pinto M (2012) Technology for the production of cocoa. 1 ed. Bogota Colombia. Produmedios p. 8-10.

5. Orozco C, Osorio C, Botero M, Rivera F, Gartner A (2011) Microbiologica and molecular evaluation of Moniliophthora perniciosa (agaricales: maras miaceae). Bull Cient Mus His Nat Univ Caldas 15(1): 41-47.

6. Doster N, Roque J, Cano A (2011) Cacao Theobroma cacao L. Botanical Leaf pp. 19.

7. Rangel M, Zavaleta H, Córdova L, López A, Delgado A, et al. (2012) Anatomy and histochemistry of the Mexican Creole cocoa bean (Theobroma cacao L.). Rev Fitotec Mex 35(3): 189-197.

8. Chinenye NM, Ogunlowo a S, Olukunle OJ (2010) Cocoa bean (Theobroma cacao L.). Drying kinetics. Chilean Journal of Agricultural Research 70(4): 633-639.

9. Lira R (2013) Plant physiology. Mexico City: Trillas pp. 59-203.

10. Castillo G, Ortega G, Carabeo V, Delgado G, Michelena G, et al. (2007) Qualitative determination of gibberellins and auxins by thin layer chromatography. ICIDCA 16(1): 12-17.

11. Macedo D, Carmem S, Marlice R, Antonio Z, Katia Z (2008) Substrates and auxins not rooting of stem cuttings of spinheirasanta. Scientia Agraria 9(1): 85-89.

12. Davies PJ (2010) Plant Hormones. (PJ Davies, Ed.) Plant Hormones: Biosynthesis, Signal Transduction, Action! Dordrecht: Springer Netherlands.
13. Ljung K (2013) Auxin metabolism and homeostasis during plant development. Development 140(5): 943-950.

14. Vanneste S, Friml J (2009) Auxin: A Trigger for Change in Plant Development. Cell 136(6): 1005-1016.

15. Robert HS, Friml J (2009) Auxin and other signals on the move in plants. Nature Chemical Biology 5(5): 325-332.

16. Gómez A, García P (2006) Phytohormones: Metabolism and mode of action. Los Angeles: USA. Editions of the Universidad Jaume I. pp. 16-18.

17. Ubeda T, García L,LópezI (2006) Molecular,Biochemical and Physiological Characterization of Gibberellin Biosynthesis and Catabolism Genes from Nerium oleander. Journal of Plant Growth Regulation 25(1): 52-68.

18. Azcón J, Talón M (2008) Fundamentals of plant physiology. $2^{\text {nd }}$ edn. Barcelona, Spain. University of Barcelona editions pp. 432-433.

19. Levitus G, Echenique V, Rubinstein C, Hopp E, Mroginski L (2010) Biotechnology and Plant Improvement II. INTA pp. 357.

20. Hicks A (2007) Orchid seed germination media, a compendium of formulations. Chandler: USA. The Orchid Seed Bank Project p. 210.

21. Jean W, Yong L, Ng YF, Tan SN (2009) The Chemical Composition and Biological Properties of Coconut (Cocos nucifera L.) Water. Molecules 14(12): 5144-5164

22. Martínez D, Menchaca R (2007) Effect of organic compounds on the in vitro propagation of Stanhopea tigrina bateman (orchidaceae). Veracruz forest 9(2): 27-32.

23. Agricultural Vademecum (2014) Hormonagro. Ecuador.

24. Nedeagro (2015) Ecohormones.

25. Agricultural Vademecum (2014) Cytoquin. Ecuador.

26. Ártica M (2008) Cocoa cultivation. MACRO Publishing Company. Peru.

27. Lázaro A, Morales A, Carbonell L, Mirafuentes F (2015) Secondary somatic embryogenesis in the cacao (Theobroma cacao L.) inifap 1 genotype and its histological description. Nova Scientia 7(2): 398-417.

28. Oliva C, Peruvian C, Benito J, Estación E, Acuña R, et al. (2014) Estimation of the repeatability and genetic selection of aromatic cacao trees with genetic material from EE-INIA-San Martin and UC de Lebuaf, in Peru. Scientia Agropecuaria 5(1): 59-64.

29. Quiroz J (2010) Clonal multiplication of cocoa by the twig rooting method. INIAP, technical bulletin No. 149: 12

30. Urrea A, Garcés L, Gallego A (2011) Regeneration via somatic embryogenesis of an elite Colombian variety of Theobroma cacao L. Rev Colomb Biotechnol 8(2): 39-50.

31. Enríquez G (2004) Organic cocoa. Guide for Ecuadorian producers. Quito, Ecuador. Manual $N^{\circ} 54$. National Autonomous Institute of Agricultural Research pp. 360

32. Gutiérrez A, Vásquez C, Álvarez J (2006) Propagation by juvenile cuttings of white balso (Heliocarpus americanus L. Sin. H. popayanensis) using sub-irrigation propagators. Revista Facultad Nacional de Agronomía, 59(2): 3479-3498.

33. Montiel O, Pastelín M, Ventura E, Castañeda O, González M, et al (2011) Elongation and rooting of Peruvian cherry vitroplants (Physalis peruviana L.). Tropical and Subtropical Agroecosystems 13(3): 537-542.

34. Cortés S, Vesga N, Sigarroa A, Yolima L, Cardenas D, et al. (2015) Substrates inoculated with microorganisms for the development of cocoa plants (Theobroma cacao L.) in the nursery stage. Bioagro 27(3): $151-158$.

35. Castillo J, López M, López J, Cetina M, Hernández T, et al. (2013) Influence factors in the rooting of cuttings of Abies Religiosa (Kunth) Schltdl. et Cham. Chapingo Magazine, Forest and Environmental Sciences Series 19(1): 175-184

36. Ramos L, Cruz N, Morante J, Villacís O (2006) Use of rooting stimulating hormones (ana and aib) for the vegetative propagation of chlorophora 
tinctoria L. gaud (fine moral) in the Ecuadorian coast. Veracruz forest. 8 (1): 9-12.

37. Fehling T, Ceccon E (2015) Macropropagation of Erythrina americanain a greenhouse: a potential tool for seasonally dry tropical forest restoration. Chapingo Magazine Forest Sciences and Environment Series 21(1): 5-16.

38. Ávila J, Jesús G Arreola, José L Rodríguez-de la O, Ricardo Trejo Calzada, David Valdez Cepeda, et al. (2013) Morphogenic responses in the in vitro propagation of pecan walnut (Carya illinoinensis [Wangenh] K. Koch). Rev Chapingo 19(3): 470-481.

39. Davies P (2013) The plant hormones: physiology, biochemistry and molecular biology. $2^{\text {nd }}$ Ed. New York: USA. Springer Science, Business Media.

\section{ISSN: 2574-1241}

DOI: $10.26717 /$ BJSTR.2021.33.005453

Cajamarca Marín Edison Stalin. Biomed J Sci \& Tech Res

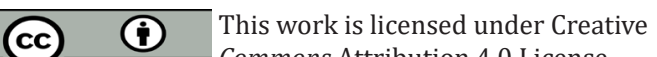
BY Commons Attribution 4.0 License

Submission Link: https://biomedres.us/submit-manuscript.php
40. López F, Guío N, Fischer G, Miranda D (2008) Propagation of cape gooseberry (Physalis peruviana L.) through different types of cuttings and substrates. Rev Fac Nal Agr Medellin 61(1): 4347-4357.

41. Martín G, Noda Y, Olivera Y, Pentón G (2015) Effect of organic products on the development of propagules of Morus alba L. Rev Mex Science Agríc 6(3): 619-625.

42. Sánchez F, Medina S, Díaz G, Ramos R, Vera J, et al. (2015). Sanitary and productive potential of 12 cocoa clones in Ecuador. Rev Fitotec Mex 38(3): 265-274

$\begin{array}{ll}\text { BIOMEDICAL } & \text { Assets of Publishing with us } \\ \text { RESEARCHES } & \text { - Global archiving of articles } \\ & \text { - Immediate, unrestricted online access } \\ & \text { - Rigorous Peer Review Process } \\ & \text { - Authors Retain Copyrights } \\ \end{array}$

